\title{
Boardroom Gender Diversity and Stock Liquidity: Evidence from Australia
}

\author{
Ammad Ahmed ${ }^{\mathrm{a}}$, Searat Ali ${ }^{\mathrm{b}, *}$ \\ ${ }^{a}$ Department of Accounting, AUT Business School, Auckland University of Technology, New Zealand. \\ ${ }^{b}$ Department of Accounting, Finance and Economics, Griffith Business School, Griffith University, Australia.
}

Revised version: May 30, 2017

\begin{abstract}
In this study, we investigate the relationship between gender-diverse boards and stock liquidity in Australia. We expect that the gender-diverse boards, with their efficient monitoring functions, lead to higher stock liquidity that has positive implications for market efficiency. Consistent with the notion, we find, using 944 Australian firms from 2008 to 2013, that boardroom gender diversity is significantly and positively associated with stock liquidity. Our findings are robust to a series of endogeneity checks and to alternative proxies for gender diversity and stock liquidity. Our results reject the assumption of women on the board as 'tokens' and also provide support to critical mass theory. We contribute to the global debate on the need for more women on corporate boards and provide comprehensive and robust evidence that suggests that having women on corporate boards is positively associated with one of the important characteristics of capital market efficiency, stock liquidity.
\end{abstract}

JEL classification: G12; G30; G34; J16

Keywords: women directors, corporate governance, stock liquidity, Australia.

\footnotetext{
خ 3 We would like to thank the editor (Ferdinand Gul) and the anonymous reviewer of the journal for their constructive comments and valuable suggestions on earlier versions of the paper. We are grateful to the discussant and other participants for their suggestions at the 2016 Conference on Business Sustainability and Corporate Governance - Performance, Reporting and Assurance in collaboration with the JCAE held in Hong Kong. We also acknowledge the conference funding support from the Technological and Higher Education Institute of Hong Kong (THEi). We are also thankful to Ben Sila for his helpful comments. We thank SIRCA for assisting us with access to the corporate governance and stock liquidity dataset. We are also grateful to Jennifer Beale and Diane Josey for their proofreading service. The authors are responsible for any remaining error.

* Corresponding author. Department of Accounting, Finance and Economics, Griffith Business School, Griffith University, 170 Kessels Road, Nathan QLD 4111, Australia. Tel.: +61 737357295

E-mail addresses: ammad.ahmed@aut.ac.nz (A. Ahmed) searat.ali@griffithuni.edu.au (S. Ali).
} 


\section{Introduction}

In this paper, we examine the effect of gender diverse boards on stock liquidity. During the last decade, boardroom gender diversity has received considerable attention from academic researchers. A large volume of empirical studies examines the 'business case' of gender diversity by focusing on the association between female directors and financial performance (Carter et al., 2010; Carter et al., 2003; Joecks et al., 2013; Liu et al., 2014; Wang and Clift, 2009); however, the results are mixed: some find evidence of beneficial effects while others report no effects, or even negative effects. Adams and Ferreira (2009) argue that female directors do not necessarily improve financial performance, but their presence may improve the monitoring function of the boards. They find that female directors are likely to serve on board monitoring committees and their presence improves overall board-meeting attendance. Their findings on the impact of female directors in exercising monitoring functions have given new dimension to the gender diversity literature and researchers are now providing empirical evidences beyond the financial performance such as agency cost (Jurkus et al., 2011), earnings quality (Srinidhi et al., 2011; Strydom et al., 2016), earnings management (Arun et al., 2015), informativeness of stock prices (Gul et al., 2011), and sustainability reporting quality (Al-Shaer and Zaman, 2016). The underlying objective of these studies is to classify female directors as one of the governance mechanisms which facilitate efficient capital market. However, when examining the effects of female directors on key financial decisions or parameters, the existing literature overlooks stock liquidity, one of the important characteristics of efficient markets.

Stock liquidity, which refers to the 'ease' of converting stock into cash or vice versa, has become a world-wide concern since the recent global financial crisis (GFC) and continues to be a prominent area of research. Handa and Schwartz (1996) stress that 'Investors want three things from the markets: liquidity, liquidity and liquidity' (p. 44). Investors require compensation for holding an illiquid stock (Amihud and Mendelson, 1986) that increases the firm's cost of equity (Butler et al., 2005), and that in turn affects the firm's value (Fang et al., 2009). Moreover, Chordia et al. (2008) suggest that poor stock liquidity is associated with a greater degree of market inefficiency. Consequently, firms strive to improve stock liquidity on account of its significant impact on the flow of capital and the development of the market, and seek to minimise conditions that impair stock liquidity (Levine and Zervos, 1996). Given the importance of stock liquidity in the financial markets for investors and firms, it is imperative to explore what determines stock liquidity. To the best of our knowledge, several studies explore other corporate governance mechanisms (e.g., board independence and ownership structure) as a determinant of stock liquidity (Ali et al., 2016; Attig et al., 2006; Chung et al., 2010) but none of them has exclusively examined the influence of female directors on stock liquidity. In this study, we fill this gap by investigating whether female directors affect stock liquidity.

Our study is further motivated by the recent regulatory upsurge in calls to include more women on corporate boards in various countries, including Australia, France, Netherlands, Norway, Sweden, and the U.K. (Lee et al., 2015). ${ }^{1}$ Specifically, the Australian Institute of Company Directors (AICD) is calling on all boards to achieve at least 30 percent women directors, and urges the Australian Securities Exchange (ASX) 200 to meet this new target by the

\footnotetext{
${ }^{1}$ The first country that legally initiated a gender quota in the boardroom was Norway. In 2003, Norway passed legislation which required 40 percent of female directors by 2008. Spain followed with the same regulation, mandating 40 percent of female directors by 2015. Other European countries which have imposed gender quotas include France (40 percent by 2016), Italy (33.3 percent by 2015), and the Netherlands (30 percent by 2016) (Lee et al., 2015).
} 
end of 2018 (AICD, 2015). The AICD’s Managing Director and Chief Executive Officer (CEO), John Brogden, said that, "There is an undeniable case for gender diversity on boards. It is not only the right thing to do but the smart thing to do" (AICD, 2015). Moreover, in 2010, the ASX Corporate Governance Council amended the ASX Corporate Governance Principles and Recommendations (ACGPR) to include increased reporting on gender diversity for all listed entities. Since then, the interest in recruiting and advancing women on boards has been growing. ${ }^{2}$ Overall, the role of female directors in enhancing monitoring quality of the board, the importance of stock liquidity in financial markets, and the recent calls for more female directors on boards provide an interesting setting to unveil debate on the impact of gender-diverse boards on stock liquidity in achieving vital objective of capital market efficiency.

Agency theory suggest that managers are opportunistic and are likely to conceal important information for their self-interest (Jensen and Meckling, 1976). Effective governance improves financial and operational transparency, thus reducing information asymmetry between insiders (e.g., managers and controlling shareholders) and outsiders (e.g., investors and liquidity providers) that in turn improves stock liquidity (Chung et al., 2010). Hillman et al. (2007) suggest that female directors bring novel perspectives and experiences to the boardroom, which improves board decision making and enhances a firm's legitimacy (Milliken and Martins, 1996). Moreover, women are risk averse and less overconfident than men, which makes them cautious in their decision making (Bajtelsmit et al., 1999; Barber and Odean, 2001; Dowling and Aribi, 2013). Jurkus et al. (2011) suggest that the representation of women on corporate boards reduces the information asymmetry between managers and shareholders and thus reduces agency conflict. Moreover, Gul et al. (2011) suggest that female directors improve stock price informativeness through increased public disclosures. Accordingly, we argue that female directors enhance board governance mechanisms (i.e. board strength) to mitigate information asymmetry problems and thus improve stock liquidity.

Our sample consists of 944 firms (4,608 firm-year observations) listed on the ASX during the period from 2008 to 2013. Our main proxy for boardroom gender diversity is the percentage of women directors. We use three different proxies for measuring stock liquidity: Amihud illiquidity estimate, liquidity ratio, and stock turnover. While controlling for other governanceand firm- specific variables, we find that the female directors are positively associated with stock liquidity. Our main results are significantly robust to alternative proxies for gender diversity and stock liquidity, as well as to endogeneity bias. As prior literature argues that having women in the boardroom is socially desirable and that exclusion of women is immoral (Campbell and Mínguez-Vera, 2008), our results provide economic significance by showing increased confidence of shareholders' and investors' in the inclusion of women on corporate boards.

In further analyses, we use average differenced variables for pre- and post-gender diversity reform to find the impact of change in the percentage of women directors on the change in liquidity measures, and the results remain consistent. We also explore the critical mass theory and non-linear relationship. The results suggest that the presence of a single woman on the board can positively influence stock liquidity, while the relationship becomes stronger when there is

\footnotetext{
${ }^{2}$ The ASX Corporate Governance Council adopted an "if not why not" approach in which companies are required to comply or explain with recommendations. Under the amendment, all listed companies are required to establish and disclose a diversity policy, measure the number of women in leadership positions, and set measurable objectives to achieve gender diversity. If the company does not comply with these recommendations, an explanation is required. According to the AICD real-time data, the percentage of women among new director appointments to ASX 200 boards increased from 5 percent in 2009 to an average of 43 percent as of January 2016. Women have made up 21.9 percent of ASX 200 board seats as of January 2016, compared with only 8.3 percent in 2009.
} 
more than one woman on the board. Moreover, the relationship between female directors and stock liquidity is not non-linear. Finally, we show that board gender diversity improves stock liquidity through board effectiveness.

Our contributions to the existing literature are threefold. First, we contribute to the boardroom gender diversity literature. Most of the prior studies examine the link between female directors and financial performance (Carter et al., 2010; Carter et al., 2003; Erhardt et al., 2003; Farrell and Hersch, 2005; Wang and Clift, 2009); however, our study is in line with only a few other studies that seek to find the impact of female directors on factors other than financial performance (Adams and Ferreira, 2009; Ahmed et al., 2015; Gul et al., 2011; Jurkus et al., 2011). To the best of our knowledge, we are the first to provide comprehensive and robust evidence of board gender diversity as a critical determinant of stock liquidity. The only exception is Loukil et al. (2015), who find no relationship between board gender diversity and stock liquidity. The scope of their study is limited due to inconsistency of their results when using different proxies of stock liquidity and the regulatory setting. ${ }^{3}$

Second, we contribute to the corporate governance literature. Prior studies that focus on the relationship between corporate governance and stock liquidity have developed a user-defined index as a proxy measure of corporate governance quality (e.g., Chung et al., 2010). Alternatively, Foo and Zain (2010) use factor analyses of board independence and board meetings as a proxy for corporate governance quality. Despite the role of gender diversity in corporate governance mechanisms (Adams and Ferreira, 2009; Gul et al., 2011), prior studies on the governance-liquidity nexus do not include gender diversity as an important instrument of corporate governance. We extend this literature by examining the effect of gender-diverse boards, as one of the important governance mechanisms, on stock liquidity.

Finally, our study is timely because gender diversity reform has resulted in significant changes in the board structure of many ASX companies. We find positive implications of gender diversity reform and suggest that women's presence on boards is beneficial for improving stock liquidity. Moreover, the results from our study disavow any assumptions that women on boards are mere 'tokens', as our results suggest that the presence of even one woman on the board has the potential to improve stock liquidity. Thus, we support the recent calls for more women on ASX corporate boards.

The remainder of the study is organised as follows. Section 2 summarises the literature and develops the research hypothesis. Section 3 describes the research design and data. Section 4 presents the results and analyses, and Section 5 concludes the study.

\section{Prior literature and hypothesis development}

Agency theory posits that management is self-serving and likely to maximise their wealth at the expense of shareholders (Jensen and Meckling, 1976). Agency conflict arises when managers disregard the interest of shareholders during the strategic decision making process. The empirical evidence supports a link between information asymmetry and agency conflict and suggests that managers tend to manipulate disclosures to maximise their personal trading in their firms' shares (Noe, 1999). Moreover, management-dominated boards are likely to be involved in fraudulent

\footnotetext{
${ }^{3}$ Loukil et al. (2015) examine the relationship between gender-diverse boards and stock liquidity in the French setting, where the impulse to increase women directors is relatively higher than in non-European countries. The urge to increase the number of women on corporate boards has resulted in a gender quota of $40 \%$ of women representation in French listed companies to be achieved by 2017. Unnecessary and mandatory gender balance may result in inefficient boards that in turn reflect poor decision making (Bøhren and Staubo, 2014).
} 
reporting and abnormal accruals (Davidson et al., 2005; Farber, 2005). In such cases, a governance mechanism is needed that can monitor managers' opportunistic behaviour and guard the rights of shareholders. Fama and Jensen (1983) suggest that an efficient board that is capable of better decision making is necessary for mitigating agency conflicts. Moreover, efficient boards enhance the monitoring function by improving the quality and the frequency of information disclosure to shareholders, which in turn reduces agency conflict (Beekes et al., 2015; Karamanou and Vafeas, 2005).

Existing literature suggests that the presence of females on corporate boards is associated with better monitoring and efficient information environment (Adams and Ferreira, 2009; Gul et al., 2011). Likewise, Gul et al. (2008) claim that female directors demand higher levels of monitoring through more audit efforts as compared to their male counterparts. Nielsen and Huse (2010) document that female directors monitor board processes related to firm strategy and organizational practices and policies, which in turn improves board effectiveness in strategic control. Abbott et al. (2012) argue that female directors with their broader perspective enhance mental independence of the board that in turn reduces the tendency of groupthink in boardroom. They further advocate that females with their better monitoring ability improve the governance mechanism, and thus reduce the likelihood of financial restatement.

Furthermore, prior literature indicates that women differ from men in leadership style by exercising trust and cooperation rather than command and compliance (Cohen et al., 1998; Trinidad and Normore, 2005). To implement this leadership style requires an extensive flow of information among directors and between directors and shareholders. If the information dissemination is inadequate between directors and shareholders, this may give rise to agency conflict. This normally occurs due to the opportunistic behaviour of managers, who possess valuable information about the company, hence increasing information asymmetry. Jurkus et al. (2011) suggest that gender-diverse boards are likely to reduce agency cost for the firm, and to align the interest of managers and shareholders. Gender-diverse boards are likely to create an affluent information environment and to improve stock price informativeness through more public disclosures (Gul et al., 2011), which in turn reduces the information asymmetry problem among directors, managers, and shareholders. By minimising the effect of asymmetric information, female directors are likely to improve earnings quality, reduce corporate opacity, and mitigate earnings management (Arun et al., 2015; Srinidhi et al., 2011; Upadhyay and Zeng, 2014).

Prior literature shows that a transparent information environment may enhance the liquidity of stocks (Gjerde et al., 2013; Lei et al., 2013). Stock liquidity is important as it influences investors' decision making. Amihud and Mendelson (2000) suggest that firms with higher stock liquidity reduce the cost of raising capital, as stock liquidity provides ease of converting cash to an investment in the stock and vice versa. Therefore, firms seek ways to improve their stock liquidity. Prior literature finds that firms with better corporate governance, which reduces information asymmetries, are likely to have more stock liquidity (Chung et al., 2010). Moreover, better corporate governance reduces firm-specific ambiguity, and moderation in ambiguity is associated with better liquidity of firms (Jiang et al., 2014).

\section{Hypothesis Development}

Despite the importance of reducing information asymmetry, managers through their opportunistic behaviour reveal less information to investors. This selective information 
disclosure raises the concern of potential investors and may distort the stock liquidity of a firm. Thus, effective monitoring governance mechanisms are needed to mitigate managements' opportunistic behaviour. Foo and Zain (2010) suggest that board independence and board diligence may reduce agency conflict through better disclosures and hence improve stock liquidity. However, prior literature on board independence as a monitoring mechanism and information disclosure is mixed. Kanagaretnam et al. (2007) suggest that board independence is negatively related to asymmetric information. Chen and Jaggi (2001) find that independent directors are positively related to the comprehensiveness of financial disclosures. On the other hand, Matolcsy et al. (2012) find no association between board independence and firm disclosure practices. This non-significant and negatively significant relationship between independent directors and information disclosure might explain that the independent directors are always less informed about the operations of the company, relying on management to provide them with value relevant information.

On the other hand, literature suggests that efficient and well-monitored boards are likely to affect stock liquidity. For example, Lei et al. (2013) have found that public companies in China experience higher stock liquidity if they have an efficient and well-governed board. Prior literature suggest that boards that meet regularly are active monitors and are more likely to perform their duties effectively in aligning the interest of managers and shareholders (Vafeas, 1999). Adams and Ferreira (2009) note that the presence of women on corporate boards increases the attendance of other board members; thus there is more chance of better monitoring and active decision making. Moreover, they find that women on boards are likely to have membership of committees such as audit and corporate governance committees, which relate to transparent reporting and earnings quality. Investors also value the addition of females to boards because of their independent thinking and better governing characteristics (Adams et al., 2011). Thus, the presence of women on corporate boards is likely to reduce investor concerns by reducing the information asymmetry between managers and shareholders and enhances board strength, which in turn improves stock liquidity. This reasoning leads to our hypothesis:

\section{H1: Women on corporate boards are positively related to stock liquidity.}

\section{Research design and data}

\subsection{Sample and data sources}

Our sample consists of 944 non-financial ASX listed firms from 2008 to 2013. The sample period is important for the reason that in 2010, the ASX Corporate Governance Council amended and included reporting on gender diversity as part of the ASX Corporate Governance Principles and Recommendations (ACGPR). Moreover, our sample includes large, medium and small sized firms, which increases the applicability of the findings to the wider economy. The data on gender diversity, governance variables and stock liquidity is taken from the Securities Industry Research Centre of Asia-Pacific (SIRCA), whereas financial data is extracted from the Morningstar database. The final sample is an unbalanced panel data set containing a total of 4,608 firm-year observations (944 unique firms over the period of 6 years). To eliminate the effect of extreme values, all the continuous variables are winsorised to the $5^{\text {th }}$ and $95^{\text {th }}$ percentile. 


\subsection{Dependent variable}

The dependent variable in our study is stock liquidity, which is measured by three different proxies. The first proxy, the Amihud illiquidity estimate (ILLIQ), captures the daily price impact of the order flow - the premium that a buyer pays or the discount that a seller concedes when executing a market order - that results from inventory and adverse selection costs (Amihud, 2002). Prior studies show that ILLIQ is a reliable measure of price impact (Hasbrouck, 2009) and stock liquidity (Carter et al., 2010; Goyenko et al., 2009; Karolyi et al., 2012; Lesmond, 2005). Consistent with Amihud (2002), we measure the Amihud illiquidity estimate (ILLIQ) as follows:

$$
I L L I Q_{i y}=\frac{1}{D_{i y}} \sum_{d=1}^{D_{i y}} \frac{\left|R_{i d y}\right|}{V O L D_{i d y}}
$$

where $\left|R_{i d y}\right|$ is the absolute stock return of firm $i$ on day $d$ of year $y, V O L D_{i d y}$ is the trading volume of firm $i$ on day $d$ of year $y, D_{i y}$ is the number of days with available data for firm $i$ in year $y$. To alleviate the impact of extreme values, we follow the literature (e.g., Brennan et al., 2013) and take the natural logarithm of the Amihud illiquidity estimate (ILLIQ).

The second proxy of stock liquidity is the liquidity ratio $(L R)$. Also known as the Amivest measure of stock liquidity, liquidity ratio $(L R)$ captures the amount of trading volume which is associated with the per unit change in the share price. Prior studies, such as those by Amihud et al. (1997) and Berkman and Eleswarapu (1998), used liquidity ratio (LR) as a proxy of stock liquidity. Consistent with Amihud et al. (1997), we measure liquidity ratio $(L R)$ as follows:

$$
L R_{i y}=\frac{\sum_{d=1}^{D i y}\left(V O L_{i d y}\right)}{\sum_{d=1}^{D i y}\left|R_{i d y}\right|}
$$

where $V O L_{i d y}$ is the daily trading volume of firm $i$ on day $d$ of year $y,\left|R_{\text {idy }}\right|$ is the absolute daily stock returns of firm $i$ on day $d$ of year $y, D_{i y}$ is the number of days with available data for firm $i$ in year $y$.

The third liquidity proxy is the stock turnover (TO), which captures trading frequency, i.e. the number of times a share changes owners. Bartov and Bodnar (1996) find a relation between information asymmetry and trading volume. They explain that information asymmetry may cause a reduction in the trading volume because uninformed traders may reduce their trades in such shares. Consistent with Datar et al. (1998), we measure stock turnover (TO) as follows:

$$
T O_{i y}=\frac{V O L_{i y}}{N_{i y}}
$$

where $V O L_{i, y}$ is the total number of shares traded for firm $i$ in a year $y$, and $N_{i, t}$ is the number of outstanding shares for firm $i$ in a year $y$. Volume data for each firm is collected on a daily basis, while the number of outstanding shares data is collected on a yearly basis.

\subsection{Explanatory and control variables}

The main independent variable in our study is boardroom gender diversity. Prior literature widely used percentage of women directors relative to total board members as a proxy of boardroom gender diversity (e.g., Adams and Ferreira, 2009; Liu et al., 2014). Thus, consistent 
with prior literature, we also use the percentage of women (Percofwomen) directors on the board as a proxy of boardroom gender diversity.

Moreover, we control for other governance and firm related characteristics that may have an impact on stock liquidity. Consistent with Foo and Zain (2010) and Prommin et al. (2014), we have included governance variables such as proportion of independent directors on the board (INDDirector), absolute number of directors on the board (BSize), and the number of meetings held by the board in a given year (BMeeting) as well as firm characteristics such as firm size (FSize), leverage $(L E V)$, return volatility $(R V o l)$, asset tangibility (ATang), share price (SPrice), firm age (FAge) and growth opportunities (GOpp) as control variables in this study.

From an agency perspective, it is argued that independent directors (INDDirector) are more effective in monitoring and controlling opportunistic behaviour of management, and are thus likely to reduce agency problems (Fama and Jensen, 1983). On the other hand, larger boards, due to the problem of free riding and increased time for decision making (coordination and communication cost), are less effective in monitoring managerial behavior (Jensen, 1993). We also control for board meetings (BMeeting) as regular board meetings improve board's ability to effectively exercise its monitoring role (Rutherford and Buchholtz, 2007) in mitigating management's opportunistic behaviour.

In terms of firm characteristics, we control for firm size (FSize) because large firms are in greater demand and attract attention from shareholders and financial analysts, which improves the information transparency (Diamond and Verrecchia, 1991). Likewise, we control for leverage ( $L E V$ ) because more levered firms exercise more transparency to mitigate the higher monitoring cost. We also control for return volatility $(R V o l)$ because more volatile stocks have more uncertainty of the cost of holding the stock, and thus such stocks have more information asymmetry and have wider bid-ask spread (Ho and Stoll, 1981). Since the payoffs of tangible assets are easy to observe, the firms with more tangible assets (ATang) are likely to have lower information asymmetry. To accurately capture the effect of tick-size-induced binding constraints, we control for the natural logarithm of the share price (SPrice). In addition to this, we control firm age (FAge) and growth opportunities (GOpp) because young and high growth firms are likely to be associated with higher information asymmetry between managers and investors.

\subsection{Model specification}

The model specification for estimating the relationship between gender diversity and stock liquidity is as follows:

$Y_{i, t}=\alpha+\beta X_{i, t}+\delta Z_{i, t}+$ Year $_{t}+$ Industry $_{i}+\varepsilon_{i, t}$

Where the subscript $i$ denotes individual firms $(i=1,2, \ldots, 944), t$ time period $(\mathrm{t}=2008$ $2009, \ldots, 2013) . \beta$ and $\delta$ are vectors of coefficients on gender diversity and governance variables $\left(X_{i, t}\right)$ and control variables $\left(Z_{i, t}\right)$ respectively; $\varepsilon_{i, t}$ is the idiosyncratic error term. We can expand equation 4 as follows:

Stock Liquidity ${ }_{i, t}$

$$
\begin{aligned}
& =\alpha+\beta_{1} \text { Percofwomen }_{i, t}+\beta_{2} \text { INDDirector }_{i, t}+\beta_{3} \text { BSize }_{i, t}+\beta_{4} \text { BMeeting }_{i, t} \\
& +\delta_{1} \text { FSize }_{i, t}+\delta_{2} \text { LEV }_{i, t}+\delta_{3} \text { RVol }_{i, t}+\delta_{4} \text { ATang }_{i, t}+\delta_{5} \text { SPrice }_{i, t}+\delta_{6} \text { FAge }_{i, t} \\
& +\delta_{7} \text { GOpp }_{i, t}+\text { Year }_{t}+\text { Industry }_{i}+\varepsilon_{i, t}
\end{aligned}
$$


where Stock Liquidity refers to Amihud illiquidity estimate (ILLIQ), liquidity ratio (LR), and stock turnover (TO). The definition and measurements of all variables are summarised in Appendix A.

To test Equation 5, we employ the pooled ordinary least squares (OLS) which estimates the time-series and cross-sectional variation of the association between gender diversity and stock liquidity. The standard errors are clustered by firm to control for heteroskedasticity and withinfirm correlation in the residuals (Petersen, 2009). ${ }^{4}$

\section{Results and analysis}

\subsection{Univariate analysis and summary statistics}

\section{[Insert Table 1 here]}

Table 1 Panel A presents the Pearson's correlation matrix of independent variables. The correlation coefficient of percentage of women on boards (Percofwomen) with the Amihud illiquidity estimate (ILLIQ) is negative and with the liquidity ratio (LR) and stock turnover (TO) is positive, suggesting that boardroom gender diversity improves stock liquidity. Prior literature used 0.7 as an acceptable threshold of correlation coefficient for independent variables (Liu et al., 2014). The magnitude of the correlation coefficient among independent variables is under 0.7; consequently, multicollinearity may not be an issue in the multivariate analysis. Moreover, the variance inflation factors (VIFs) for all the explanatory variables (untabulated) are less than ' 10 ', which further confirms non-multicollinearity among independent variables.

Table 1 Panel B presents the descriptive statistics of the dependent and independent variables. In terms of stock liquidity, the means of Amihud illiquidity estimate (ILLIQ), liquidity ratio $(L R)$, and stock turnover $(T O)$ are -14.12 , 3.97, and 0.49 respectively. Table 1 Panel B further shows the descriptive statistics of our main independent variable (percentage of women directors) and its two alternative measures (women to men ratio and presence of at least one woman on the board). On average, the sample firms comprise 6 percent of women directors (Percofwomen) and the average ratio of women directors to their counterparts (Percwomen2men) is 5 percent. The mean of the women dichotomous variable (Womend) is approximately 0.27 , suggesting that 27 percent of the sample firms have at least one woman director on their board. In governance-related variables, average firms have 5.92 board members (BSize), of which 44 percent are independent members (INDDirector), and they meet (BMeeting) approximately 10 times a year. In contrast to other studies (e.g., Adams and Ferreira, 2009; Gul et al., 2011), the average board size and board independence in our sample are relatively small. This might be attributable to the inclusion of medium- and small-sized firms in our sample, as these firms are likely to have small board size and low board independence. In terms of firm characteristics, an average sample firm has \$1,330 Million as assets (FSize) and carries 35 percent debt in its capital structure. Return volatility $(\mathrm{RVol})$ and asset tangibility (ATang) averages are 0.04 and 0.21

\footnotetext{
${ }^{4}$ Generally, the firm fixed-effect (FE) is employed in the presence of unobserved firm fixed effects (see e.g., Nakano and Nguyen, 2012; Pathan, 2009). However, FE may not be suitable for our study because it requires significant variation in the variables to generate consistent and unbiased estimates. In our study, the variable of interest, i.e., boardroom gender diversity, does not vary substantially over time; therefore the FE estimates would be imprecise (Wooldridge, 2002: p. 286). Second, for large number of firms ' $N$ ' and fixed limited time ' $T$ ', which is the case in our study (944 firms over 6 years), FE provides inconsistent estimation (Baltagi, 2005: p. 13).
} 
respectively. The average stock price (SPrice) is -0.89 and the average age is 15.58 years (FAge) with growth opportunities (GOpp) of 2.21.

Table 1 Panel C presents the univariate analyses of firms with and without women on their boards. We observe a significant mean difference in all the stock liquidity measures between firms with and without women on board. For instance, the Amihud illiquidity estimate (ILLIQ) is significantly lower for the firms with women on boards (-15.61) than for the firms without women on their boards (-13.51), implying that firms with gender-diverse boards have a greater stock liquidity compare to all male boards. We also observe a significant mean difference in almost all the control variables between firms with and without women on their boards. In particular, compared to the firms without women on their boards, the firms with women on their boards have significantly larger and more independent boards that meet more often in a given financial year. Furthermore, we observe that firms with women on their boards are larger in size and older in age, have more asset tangibility, have high debt in their capital structure, have a higher share price, and have lower return volatility. These comparisons suggest that governance and firm related characteristics could influence the choices of firms in appointing women directors to their boards. Therefore, it is important to control for these characteristics in our multivariate analysis.

Table 1 Panel D presents the sample distribution and descriptive statistics by year and industry. We note a gradual increase in percentage (21.81 to 34.37 percent) of firms with women on boards (Womend) from 2008 to 2013. Similarly, the percentage of women on boards (Percofwomen) steadily increases from 4.51 percent in 2008 to 7.64 percent in 2013. The percentage of women on boards (Percofwomen) in our sample is low due to several reasons. First, our sample is not restricted to Top200 firms that are inclined to have more women on their boards due to their size and institutional pressure (Peng, 2004). Second, we exclude financial sector firms; a recent survey on the women in boardrooms suggests that the financial sector tops all industries in terms of having more women on boards (Deloitte, 2015). In terms of stock liquidity, however, we do not find a systematic rising trend, although we observe significant improvement in stock liquidity surrounding the gender diversity reform period of 2010. For instance, comparing the average stock liquidity of 2009 with that of 2011, we observe that the Amihud illiquidity estimate (ILLIQ) decreased from -13.28 to -14.55 , the liquidity ratio $(L R)$ increased from 2.41 to 5.09 and the stock turnover (TO) increased from 0.40 to 0.54 . Overall, these trends in gender diversity and stock liquidity suggest the necessity of year fixed effect (Year) in the model.

Table 1 Panel D further provides the sample distribution and descriptive statistics by Global Industry Classification Scheme (GICS). Consumer discretionary (CD), consumer staples (CS), and health care $(H C)$ are the top three industries in terms of having a gender-diverse board. Moreover, these industries are also among the top industries that have the highest percentage of women on boards ( 9.21 percent in consumer discretionary, 8.76 in consumer staples, and 8.75 in health care). On the other hand, the materials $(M)$ and energy $(E)$ sectors have the lowest percentage of women on boards (3.52 and 4.16 percent respectively). In terms of stock liquidity, we observe substantial differences across industries. For instance, the Amihud illiquidity estimate (ILLIQ) is lowest (-15.10) in consumer staples (CS) and is highest (-13.08) in information technology (IT), whereas liquidity ratio $(L R)$ is lowest (1.97) in information technology and is highest in energy (5.56). These variations across industries suggest the necessity of industry fixed effect (Industry) in the model. 


\subsection{Multivariate analysis}

\subsubsection{Main results}

Table 2 provides the pooled OLS regression results of the association between gender diversity and stock liquidity. We estimate the relationship between stock liquidity and gender diversity in three different models. The first model (Model 1) presents the relationship between percentage of women on boards (Percofwomen) and Amihud illiquidity estimate (ILLIQ) while controlling other governance and firm related variables. The results from the first model suggest that gender diversity on corporate boards is significantly and negatively related to stock illiquidity. In Model 1, the coefficient on percentage of women on boards (Percofwomen) is 0.96, which suggests that a 1 percent increase in women on boards reduces the stock illiquidity by 0.96 points. The second and third models (Models 2 and 3) present the relationship of percentage of women on boards (Percofwomen) with liquidity ratio (LR) and stock turnover (TO) respectively. The results from Models 2 and 3 shows that gender diversity is significantly and positively associated with stock liquidity. The coefficient of percentage of women on boards (Percofwomen) in Models 2 and 3 is 0.54 and 0.19 respectively, which suggests that a 1 percent increase in percentage of women on boards (Percofwomen) may improve liquidity ratio ( $L R$ ) and stock turnover (TO) by 0.54 and 0.19 points respectively. Our results have economic meaning as well. For instance, an increase in percentage of women on boards (Percofwomen) by one standard deviation is likely to decrease the Amihud illiquidity estimate (ILLIQ) by 0.68 percent. $^{5}$ Similarly, an increase in percentage of women on boards (Percofwomen) by one standard deviation is likely to improve liquidity ratio $(L R)$ and stock turnover (TO) by 1.36 percent and 3.88 percent respectively.

Overall, these results are in line with our hypothesis that women on corporate boards are significantly and positively related to the stock liquidity. Moreover, our results support the prior stream of literature that advocates the importance of women on corporate boards in improving overall governance function (Adams and Ferreira, 2009; Gul et al., 2011; Jurkus et al., 2011). Specifically, our results suggest that women on corporate board, through their monitoring and oversight ability, are likely to affect the stock liquidity of a firm. Prior literature also suggests that better disclosure and better alignment of shareholders' and managers' interest are determinants of higher stock liquidity. Thus, our study indirectly implies that having women on corporate boards enhances the information environment and reduces the agency problem, which in turn improves stock liquidity. Additionally, our results complement prior studies that suggest better-governed firms are likely to have more stock liquidity (Ali et al., 2016; Chung et al., 2010; Foo and Zain, 2010; Prommin et al., 2014).

\section{[Insert Table 2 here]}

\subsubsection{Endogeneity and self-selection bias}

One possible concern in our regression analyses might be the issue of endogeneity, which assumes that female representation on corporate boards does not influence stock liquidity, and

\footnotetext{
${ }^{5}$ We multiply the standard deviation of boardroom gender diversity (Percofwomen) i.e., 0.10, with the coefficient on boardroom gender diversity (Percofwomen) i.e., -0.96 in Model 1 of Table 2, to get -0.096 . Therefore, one standard deviation increase in the boardroom gender diversity decreases Amihud illiquidity estimate (ILLIQ) by -0.096 points. As the mean Amihud illiquidity estimate (ILLIQ) is -14.12 , a decrease by 0.096 denotes a change by $0.68 \%$ of the average stock illiquidity.
} 
that firms with higher stock liquidity are likely to attract more women on their boards. Moreover, some women may non-randomly self-select their employer, making it a choice variable, dependent on a variety of factors. Ignoring these important assumptions may lead to imprecise estimates. Consequently, to alleviate possible endogeneity (e.g., reverse causality) and selfselection bias, we employ three techniques: lagged independent variables, two-stage least squares (2SLS), and propensity score matching (PSM).

The first technique, the use of lagged independent variables, is widely acceptable in corporate governance literature to minimise the effect of reverse causality (e.g., Wintoki et al., 2012). Table 3 provides the results of the association between gender diversity and stock liquidity by using lagged independent variables. Similar to our main results, percentage of women on boards (Percofwomen) is significantly and negatively related to Amihud illiquidity estimate (ILLIQ) and significantly and positively related to liquidity ratio (LR), while it has no effect on stock turnover (TO). Two out of three liquidity measures support our main results and subsequently confirm that female representation on corporate boards affects stock liquidity, but not vice versa.

\section{[Insert Table 3 here]}

In the second technique, consistent with Adams and Ferreira (2009), we adopt a 2SLS instrumental variable approach to minimise the possible endogeneity. This approach has been extensively used in the prior literature to mitigate endogeneity bias such as omitted variable, measurement error, and reverse causality (e.g., Liu et al., 2014). This approach requires the creation of an exogenous variable (instrumental variable) that is correlated with the main independent variable and that should not have a direct relationship with the dependent variable. To achieve this objective, we select the passage of the gender diversity reform of 2010 as our instrumental variable (Jiraporn et al., 2015). We create a dummy variable, namely gender reform (GReform), that is equal to ' 1 ' for the years from 2011 to 2013 and '0' otherwise. The idea of using gender reform (GReform) as an instrumental variable is based on the assumption that in the post reform period women on boards should be higher, suggesting a strong correlation between women on boards and gender reform (GReform). We assume that the gender reform is correlated with the representation of women on corporate boards and does not have a direct relationship with stock liquidity.

Table 4 Model 1 presents the results of the first-stage regression, where percentage of women on boards (Percofwomen) is the dependent variable. ${ }^{6}$ The coefficient of gender reform (GReform) is statistically significant and positive. This result suggests that gender diversity is considerably higher after the enactment of gender diversity reforms, proving it to be a valid instrument for 2SLS regression. Then in Models 2-4, we use the predicted percentage of women on boards (Fitted_Percofwomen) with stock liquidity measures (i.e., ILLIQ, LR, and TO). ${ }^{7}$ Consistent with our main results, the 2SLS finds a statistically significant and negative relationship between female directors and Amihud illiquidity estimate (ILLIQ) and a statistically

\footnotetext{
${ }^{6}$ Year fixed effects are excluded from the 2SLS model because the instrumental variable, GReform, is highly correlated with year dummies. Furthermore, the exclusion of year dummies is consistent with the prior literature (see e.g., Jiraporn et al., 2015).

${ }^{7}$ In models 3 and 4 , small value of $\mathrm{R}^{2}$ may indicate poor fitness of the models but the $\mathrm{R}^{2}$ has no statistical meaning in the context of 2SLS due to lack of orthogonality of regressors and the errors. Due to such issues, the $\mathrm{R}^{2}$ is not reported in the 2SLS model in Adams and Ferreira (2009).
} 
significant and positive relationship between female directors and liquidity ratio $(L R)$ and turnover (TO). These results from 2SLS regression confirm that our earlier findings are not driven by endogeneity.

\section{[Insert Table 4 here]}

Finally, we employ the propensity score matching (PSM) technique to minimise the potential self-selection bias. PSM is a widely acceptable technique to minimise any self-selection bias that occurs when predictors of an outcome are themselves related to other observed or unobserved variables (Titus, 2007). In their study, Farrell and Hersch (2005) argue that the shortage of qualified women offers women the luxury of self-selection to serve on the boards of better performing firms. In this case, gender diversity on corporate boards may not be systematically associated with stock liquidity.

Consistent with Lennox et al. (2013), we adopt a two-step PSM to check the sensitivity of our main results. In the first step, we use the women dummy variable (Womend), which takes the value ' 1 ' for at least one woman on the board and ' 0 ' otherwise, to distribute sample firms into two groups: one with women on the board (treatment firms) and the other without women on the board (control group). Then we use the logistic regression for women dummy (Womend) and governance and firm related variables to get the predicted estimates that are used as the propensity scores for each firm-year observation in the next step. These propensity scores are used in the second stage to find the matched pairs for firms with women on their boards. This results in 2,461 effectively matched firm-year observations. After performing the PSM technique, any difference in the outcome variables (i.e., ILLIQ, $L R$, and TO) can be attributed to differences in percentage of women on boards (Percofwomen) rather than to the differences in other variables.

Table 5 Model 1 presents the results of the first-stage regression, where the women dichotomous variable (Womend) is the dependent variable. We find that the presence of at least one woman on the board is more frequent for firms with greater board independence (INDDirector), board size (BSize), firm size (FSize), and firm age (FAge). However, the presence of at least one woman on the board is less for firms with more board meetings (BMeeting), return volatility ( $R V O l)$ and growth opportunities (GOpp). Models 2-4 capture the results of the second stage regression, and suggest that boardroom gender diversity significantly and positively affects stock liquidity (ILLIQ, $L R$, and TO). These results confirm that the variation in stock liquidity is attributable to the systematic difference in the presence of women on boards.

\section{[Insert Table 5 here]}

\subsection{Further analyses and robustness checks}

\subsubsection{Gender diversity and stock liquidity surrounding the reforms}

As the ASX Corporate Governance Council amended and included reporting on gender diversity as part of the ASX Corporate Governance Principles and Recommendations (ACGPR) in 2010, our sample allows us to analyse the effect of boardroom gender diversity on stock liquidity based on pre- and post-gender diversity reform periods. In doing so, we use only surviving firms throughout the sample period and then divide the sample period into pre- (2008 to 2010) and post- (2011 to 2013) reforms. For analysis purposes, we calculate the average difference of all variables based on the pre- and post-reform periods. Table 6 presents the results 
of the association between average differenced variables from pre- and post-gender diversity recommendations and stock liquidity. The results are consistent with our main results reported in Table 2, suggesting a statistically significant negative relationship of percentage of women on the board (Percofwomen) with the Amihud illiquidity estimate (ILLIQ) and a statistically significant positive relationship with liquidity ratio $(L R)$ and stock turnover (TO). Moreover, these findings suggest that the change in the level of gender diversity from pre- to post-gender diversity recommendations is associated with the change in stock liquidity.

\section{[Insert Table 6 here]}

\subsubsection{Critical mass theory, non-linear relationship and alternate proxies}

Proponents of critical mass theory suggest that women on boards are likely to influence the board decision making process when there is more than one woman on the board (Kramer et al., 2006). Moreover, Kristie (2011) summarises the critical mass theory by suggesting that one woman is a 'token', two women is a 'presence', and three or more women is a 'voice'. Thus, we seek to examine if the presence of more than one woman on the board improves the relationship between gender diversity and stock liquidity. To achieve this objective, consistent with Liu et al. (2014), we create three dummy variables: Womend1 (value of ' 1 ' if the firm has only one woman on the board and ' 0 ' otherwise), Womend 2 (value of ' 1 ' if the firm has two women on the board and ' 0 ' otherwise), and Womend3 (value of ' 1 ' if the firm has more than two women on the board and ' 0 ' otherwise). ${ }^{8}$

The results of critical mass theory are reported in Panel A of Table 7. The results suggest that the relationship between firms with only one woman on their board (Womend1) and stock liquidity is significant and positive, for $L R$ and $T O$, but weak in magnitude; however the relationship improves for firms with two women on their board (Womend2) for all stock liquidity measures and become even stronger for firms with more than two women on their board (Womend3). This result provides support for the critical mass theory and suggests that, even though the presence of at least one woman on the board influences stock liquidity, the relationship becomes more significant and stronger when there is more than one woman on the board.

\section{[Insert Table 7 here]}

Since the presence of more than one woman on the board improves the relationship between gender diversity and stock liquidity, it is important to find if this relationship is linear or nonlinear in nature. To empirically check the linearity between the gender-liquidity nexus, we include the square term of percentage of women on boards (Percofwomen ${ }^{2}$ ) in the main model. The results in Panel $\mathrm{B}$ of Table 7 report that the percentage of women (Percofwomen) is statistically significant for $L R$ and TO; however, the square of percentage of women $\left(\right.$ Percofwomen $\left.^{2}\right)$ is not significant. This suggests that the relationship between gender diversity and stock liquidity is not non-linear.

To further check the robustness of our results, we use three alternative proxies of gender diversity: women to men ratio (Percwomen2men), a dichotomous variable ' 1 ' for the presence of women on corporate boards and ' 0 ' otherwise (Womend), and the Blau index (Blau) developed by Blau (1977) (see, Harrison and Klein, 2007). Our results (untabulated) suggest that all three

\footnotetext{
${ }^{8}$ The summary statistics (untabulated) show that about $20 \%$ of firms have one, $5 \%$ of firms have two, and $1 \%$ of firms have three or more women directors, while the remaining $76 \%$ have only male directors on their board.
} 
alternative proxies of gender diversity support our main results. We also use three alternate proxies of stock liquidity: number of trades (Trade), number of levels (Level), and trading volume (Volume) (Chordia et al., 2001). ${ }^{9}$ The results (untabulated) indicate that gender diversity is significantly and positively related with stock liquidity (Trade, Level, and Volume). Overall, these findings are consistent with our main findings reported in Table 2 and confirm that our main results are robust after considering alternate gender diversity and stock liquidity proxies.

\subsubsection{Gender diversity, board strength and stock liquidity}

Since we posit a link between boardroom gender diversity and stock liquidity through effectiveness of corporate boards, we examine whether boardroom gender diversity is associated with the board effectiveness, and whether board effectiveness improves stock liquidity. ${ }^{10}$ To examine these associations, we employ a proxy for board effectiveness, i.e. the board strength index based on the independence of the board and its subcommittees (audit, nomination, remuneration). Specifically, we follow Ali et al. (2014) and construct a board strength index (BStrength) based on 17 governance provisions (see Appendix B). By using equally weighted scoring methodology, we assign the value ' 1 ' if a firm meets particular criteria and ' 0 ' otherwise. We then aggregate these individual values to construct a board strength index (range 0 to 17) where ' 0 ' indicates the 'weak' board and ' 17 ' indicates the 'strong' board.

\section{[Insert Table 8 here]}

Table 8 Model 1 presents the results on boardroom gender diversity and board strength, Models 2-4 show the results on board strength and stock liquidity, and Models 5-7 display the results on boardroom gender diversity, board strength and stock liquidity. ${ }^{11}$ The results from Model 1 suggest that gender diversity at board level (Percofwomen) is significantly and positively associated with board strength (BStrength). Results of Models 2-4 indicate that board strength (BStrength) is significantly and positively associated with stock liquidity (ILLIQ, LR, and TO). Finally, while controlling for board strength (BStrength), models 5-7 suggest women on corporate boards (Percofwomen) to be still significantly associated with stock liquidity (ILLIQ, LR, and TO). Overall, these findings suggest that women on corporate boards improve stock liquidity because it is related to the improvement in board effectiveness.

\section{Conclusion}

Given the proliferating attention of regulators and researchers on boardroom gender diversity and the pertaining gap in the gender diversity literature, our study is timely to examine the implications of female participation on the corporate boards. Specifically, we examine the influence of boardroom gender diversity on stock liquidity based on 944 ASX listed firms over the period from 2008 to 2013. Our results suggest that women on boards are significantly and positively associated with stock liquidity. These results remain consistent when we use alternative proxies for gender diversity and stock liquidity. To minimise possible endogeneity and self-selection bias, we perform a series of sensitivity tests including lagged independent variables, an instrumental variable approach, and the propensity score matching technique. The

\footnotetext{
${ }^{9}$ The number of trades (Trade) is measured as the average number of transactions in a financial year. The number of levels (Level) is measured as the yearly average of the number of price levels available at a particular time in the order book. It is also referred to as the depth of the order book. The trading volume (Volume) is measured as the natural logarithm of the total number of shares traded (in dollars) in a financial year.

${ }^{10}$ We thank the conference participants for suggesting this additional test.

${ }^{11}$ Since board independence (INDDirector) and board meetings (BMeeting) are part of the board strength index, we omit these two variables from the model to avoid multicollinearity.
} 
results from these sophisticated tests support the notion that women on boards affect stock liquidity, not vice versa.

In further analyses, we document that the change in the percentage of women on boards from pre- to post-gender diversity reform is associated with the change in stock liquidity. We also test for critical mass theory and linearity of relationship between gender-diverse boards and stock liquidity. We find that the presence of only one woman director is also associated with positive improvement in stock liquidity, while the influence become stronger in the presence of two and three or more women on board. These results reject the assumption of women as 'tokens' and support the critical mass theory. While examining the linearity of the relationship, we find that the relationship between gender-diverse boards and stock liquidity is not non-linear (i.e., not subject to reversal after reaching a certain point). Finally, to assess our argument of women on boards improve stock liquidity by increasing board strength, we examine the association between 1) women on boards and board strength, 2) board strength and stock liquidity, and 3) women on boards and stock liquidity by controlling board strength. Notably, the results support our argument that women on boards improve stock liquidity through increasing board strength.

Our study contributes to the current debate on the implications of having women on boards by providing first (to the best of our knowledge) comprehensive and robust evidence on the positive and significant influence of female directors on stock liquidity. Overall, these findings support the calls for more women on ASX boards and opens new avenues for future research in determining the relationship between gender-diverse boards and other characteristics of efficient capital market such as financial stability and insolvency risk. 
Table 1

Summary statistics and univariate analysis

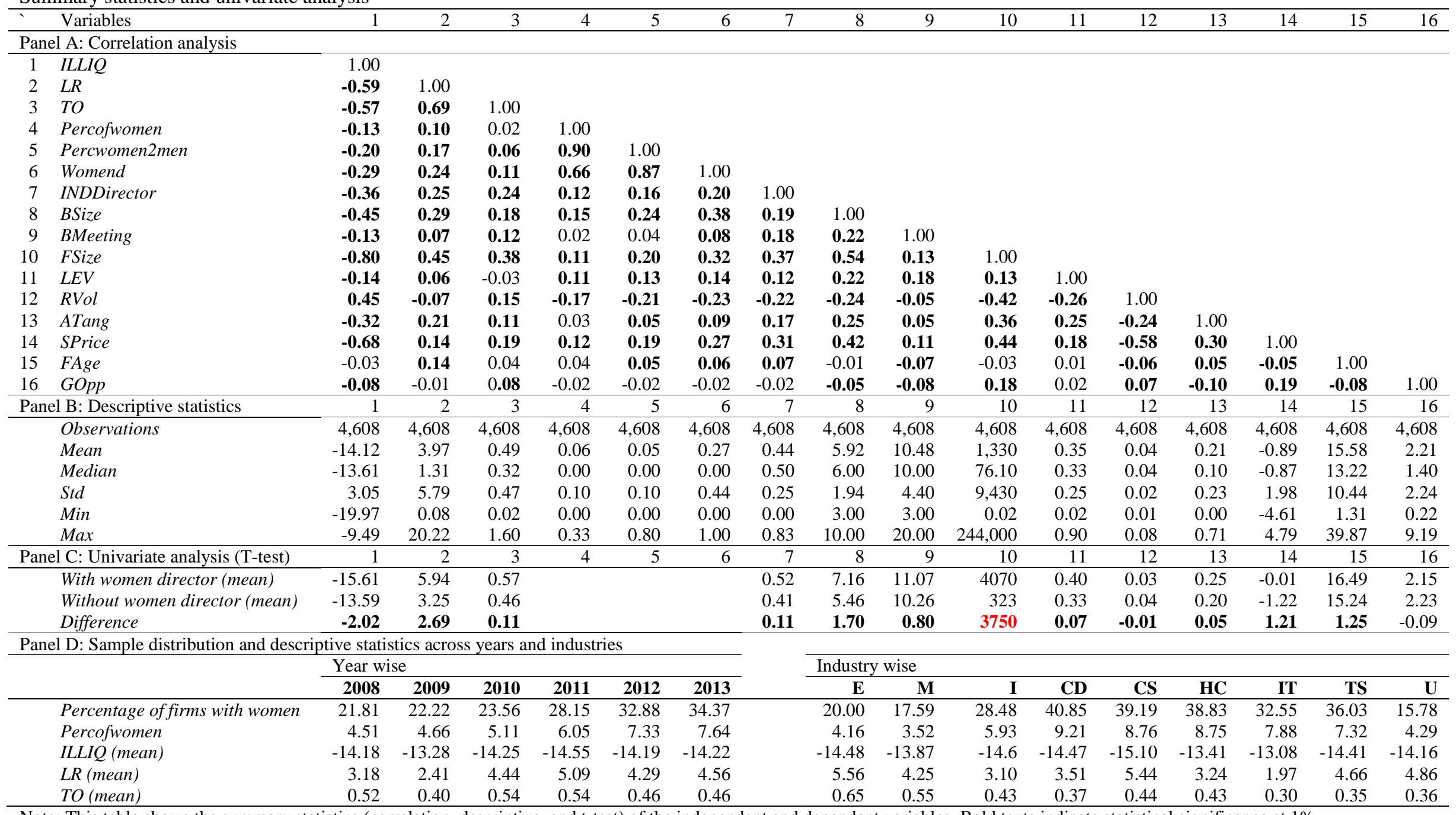

Note: This table shows the summary statistics (correlation, descriptive, and t-test) of the independent and dependent variables. Bold texts indicate statistical significance at $1 \%$

level or better. FSize is taken in amount instead of natural logarithm in descriptive statistics to make it meaningful. See Appendix A for variable definitions. 
Table 2

Gender diversity and stock liquidity (Pooled OLS regression)

\begin{tabular}{|c|c|c|c|}
\hline & $\begin{array}{r}\text { Model } 1 \\
\text { (t-stats) }\end{array}$ & $\begin{array}{r}\text { Model } 2 \\
\text { (t-stats) }\end{array}$ & $\begin{array}{r}\text { Model } 3 \\
\text { (t-stats) }\end{array}$ \\
\hline Dependent variables & ILLIQ & $L R$ & TO \\
\hline \multicolumn{4}{|c|}{ Gender diversity variable } \\
\hline Percofwomen & $\begin{array}{r}-0.96 * * \\
(-2.04)\end{array}$ & $\begin{array}{r}0.54 * * \\
(2.18)\end{array}$ & $\begin{array}{r}0.19 * * \\
(2.04)\end{array}$ \\
\hline \multicolumn{4}{|c|}{ Governance related variables } \\
\hline INDDirector & $\begin{array}{r}-0.81 * * * \\
(-4.64)\end{array}$ & $\begin{array}{r}0.65^{* * * *} \\
(5.56)\end{array}$ & $\begin{array}{r}0.25^{* * *} \\
(6.68)\end{array}$ \\
\hline BSize & $\begin{array}{r}-0.04 \\
(-0.33)\end{array}$ & $\begin{array}{r}0.01 \\
(0.12)\end{array}$ & $\begin{array}{r}-0.06 * * \\
(-2.01)\end{array}$ \\
\hline BMeeting & $\begin{array}{l}-0.19 * \\
(-1.84)\end{array}$ & $\begin{array}{r}0.14^{* *} \\
(2.15)\end{array}$ & $\begin{array}{r}0.06 * * * \\
(3.16)\end{array}$ \\
\hline \multicolumn{4}{|l|}{ Firm related variables } \\
\hline FSize & $\begin{array}{r}-1.14^{* * *} \\
(-20.08)\end{array}$ & $\begin{array}{r}0.98 * * * \\
(28.95)\end{array}$ & $\begin{array}{r}0.12^{* * * *} \\
(11.32)\end{array}$ \\
\hline LEV & $\begin{array}{r}-0.45 * * \\
(-2.18)\end{array}$ & $\begin{array}{r}0.16 \\
(1.32)\end{array}$ & $\begin{array}{r}0.10 * * \\
(2.22)\end{array}$ \\
\hline RVol & $\begin{array}{r}28.11^{* * *} \\
(8.77)\end{array}$ & $\begin{array}{r}6.63 * * * \\
(3.00)\end{array}$ & $\begin{array}{r}9.78 * * * \\
(14.87)\end{array}$ \\
\hline ATang & $\begin{array}{r}0.17 \\
(0.69)\end{array}$ & $\begin{array}{r}-0.12 \\
(-1.02)\end{array}$ & $\begin{array}{r}-0.02 \\
(-0.49)\end{array}$ \\
\hline SPrice & $\begin{array}{r}0.07 \\
(1.39)\end{array}$ & $\begin{array}{r}-0.74 * * * \\
(-21.51)\end{array}$ & $\begin{array}{r}-0.01 \\
(-1.08)\end{array}$ \\
\hline FAge & $\begin{array}{r}-0.10^{* *} \\
(-1.98)\end{array}$ & $\begin{array}{r}0.09 * * * \\
(2.80)\end{array}$ & $\begin{array}{r}0.03 * * * \\
(2.86)\end{array}$ \\
\hline GOpp & $\begin{array}{l}0.03^{*} \\
(1.82)\end{array}$ & $\begin{array}{r}-0.01 \\
(-1.07)\end{array}$ & $\begin{array}{r}-0.00 \\
(-1.59)\end{array}$ \\
\hline Year fixed effects & Yes & Yes & Yes \\
\hline Industry fixed effects & Yes & Yes & Yes \\
\hline Constant & $\begin{array}{r}7.75 * * * \\
(7.27)\end{array}$ & $\begin{array}{r}-20.28 * * * \\
(-34.86)\end{array}$ & $\begin{array}{r}-2.70 * * * \\
(-14.00)\end{array}$ \\
\hline $\mathrm{R}^{2}$ & 0.68 & 0.60 & 0.34 \\
\hline Obs. & 4,608 & 4,608 & 4,608 \\
\hline
\end{tabular}

See Appendix A for variable definitions.

Figures in parenthesis are the t-statistics. Superscripts ***, **, * indicate statistical significance at $1 \%, 5 \%$, and $10 \%$ respectively. 
Table 3

Gender diversity and stock liquidity (Lagged independent variables)

\begin{tabular}{|c|c|c|c|}
\hline & $\begin{array}{r}\text { Model } 1 \\
\text { (t-stats) }\end{array}$ & $\begin{array}{r}\text { Model } 2 \\
\text { (t-stats) }\end{array}$ & $\begin{array}{r}\text { Model } 3 \\
\text { (t-stats) }\end{array}$ \\
\hline Dependent variables & ILLIQ & $L R$ & TO \\
\hline \multicolumn{4}{|c|}{ Gender diversity variable } \\
\hline Percofwomen $_{t-1}$ & $\begin{array}{r}-0.95 * * * \\
(-3.03)\end{array}$ & $\begin{array}{r}0.45^{* * *} \\
(2.63)\end{array}$ & $\begin{array}{r}0.09 \\
(1.46)\end{array}$ \\
\hline \multicolumn{4}{|c|}{ Governance related variables } \\
\hline INDDirector $_{t-1}$ & $\begin{array}{r}-0.73 * * * \\
(-5.53)\end{array}$ & $\begin{array}{r}0.67 * * * \\
(9.24)\end{array}$ & $\begin{array}{r}0.24 * * * \\
(8.80)\end{array}$ \\
\hline BSize $_{t-1}$ & $\begin{array}{r}0.31 * * * \\
(2.77)\end{array}$ & $\begin{array}{r}-0.04 \\
(-0.75)\end{array}$ & $\begin{array}{r}-0.09 * * * \\
(-4.01)\end{array}$ \\
\hline BMeeting $_{t-1}$ & $\begin{array}{r}-0.17 * * \\
(-2.57)\end{array}$ & $\begin{array}{r}0.08 * * \\
(2.12)\end{array}$ & $\begin{array}{r}0.05 * * * \\
(3.42)\end{array}$ \\
\hline \multicolumn{4}{|l|}{ Firm related variables } \\
\hline FSize $_{t-1}$ & $\begin{array}{r}-1.13 * * * \\
(-33.82)\end{array}$ & $\begin{array}{r}0.99 * * * \\
(54.58)\end{array}$ & $\begin{array}{r}0.17 * * * \\
(24.60)\end{array}$ \\
\hline$L E V_{t-1}$ & $\begin{array}{r}-0.35^{* *} \\
(-2.34)\end{array}$ & $\begin{array}{r}0.27 * * * \\
(3.32)\end{array}$ & $\begin{array}{r}0.08 * * * \\
(2.62)\end{array}$ \\
\hline$R V o l_{t-1}$ & $\begin{array}{r}11.11^{* * *} \\
(4.81)\end{array}$ & $\begin{array}{r}9.68 * * * \\
(7.83)\end{array}$ & $\begin{array}{r}5.70 * * * \\
(11.91)\end{array}$ \\
\hline $\operatorname{ATang}_{t-1}$ & $\begin{array}{r}0.07 \\
(0.52)\end{array}$ & $\begin{array}{r}-0.11 \\
(-1.40)\end{array}$ & $\begin{array}{r}-0.01 \\
(-0.53)\end{array}$ \\
\hline SPrice $_{t-1}$ & $\begin{array}{r}-0.09 * * * \\
(-2.82)\end{array}$ & $\begin{array}{r}-0.73 * * * \\
(-40.57)\end{array}$ & $\begin{array}{r}-0.06 * * * \\
(-9.17)\end{array}$ \\
\hline$F A g e_{t-1}$ & $\begin{array}{l}-0.06 * \\
(-1.80)\end{array}$ & $\begin{array}{c}0.03^{*} \\
(1.78)\end{array}$ & $\begin{array}{r}0.01 \\
(0.64)\end{array}$ \\
\hline$G O p p_{t-1}$ & $\begin{array}{r}-0.01 \\
(-0.56)\end{array}$ & $\begin{array}{r}-0.01 \\
(-1.33)\end{array}$ & $\begin{array}{r}0.00 \\
(0.14)\end{array}$ \\
\hline Year fixed effects & Yes & Yes & Yes \\
\hline Industry fixed effects & Yes & Yes & Yes \\
\hline Constant & $\begin{array}{r}8.24 * * * \\
(11.71)\end{array}$ & $\begin{array}{r}-20.50 * * * \\
(-53.03)\end{array}$ & $\begin{array}{r}-3.29 * * * \\
(-22.02)\end{array}$ \\
\hline $\mathrm{R}^{2}$ & 0.67 & 0.60 & 0.34 \\
\hline Obs. & 3,738 & 3,738 & 3,738 \\
\hline
\end{tabular}

See Appendix A for variable definitions.

Figures in parenthesis are the t-statistics. Superscripts ***, **, * indicate statistical significance at $1 \%, 5 \%$, and $10 \%$ respectively. 
Table 4

Gender diversity and stock liquidity (Two-stage least squares)

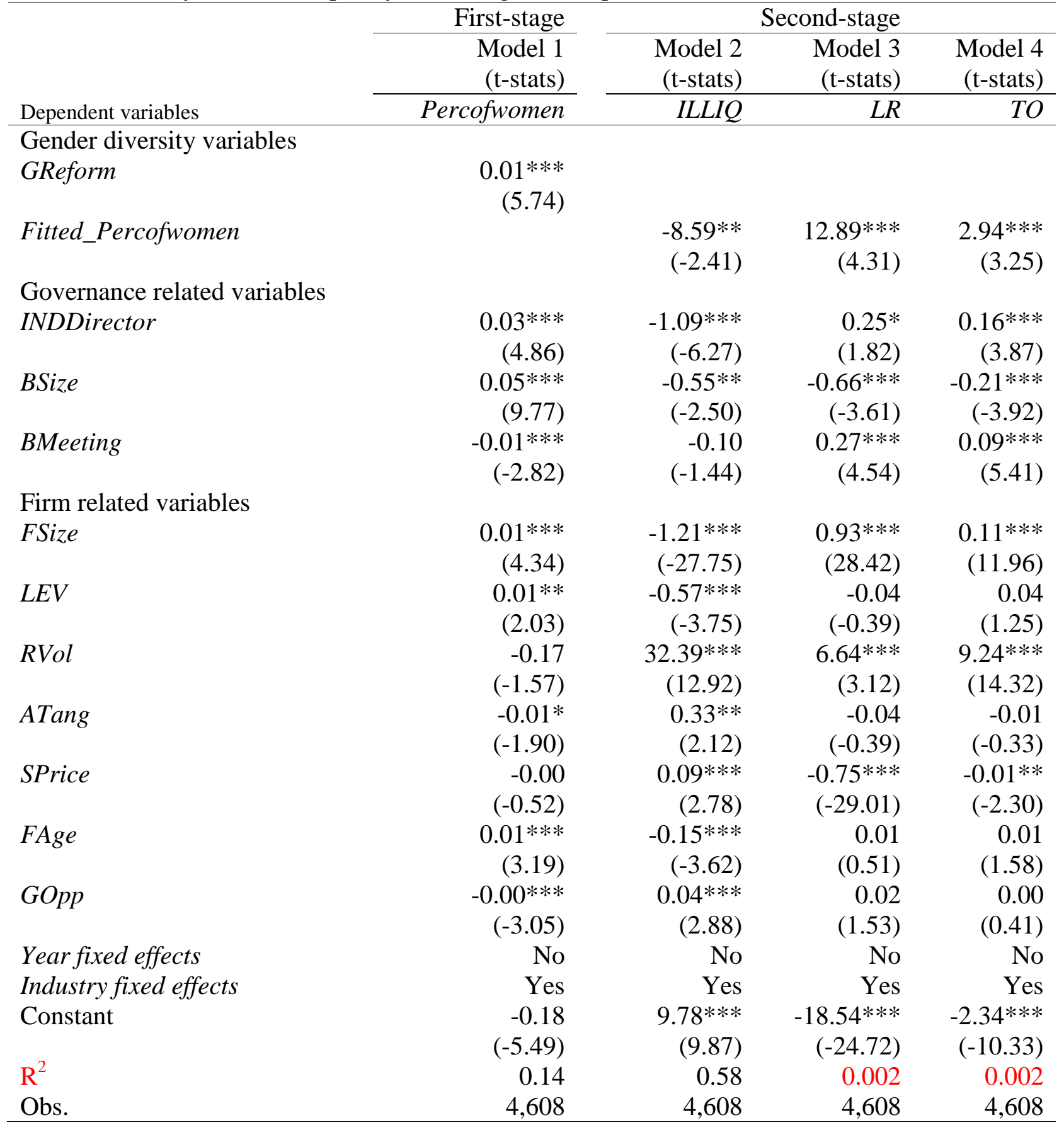

See Appendix A for variable definitions.

Figures in parenthesis are the t-statistics. Superscripts ***, **, * indicate statistical significance at $1 \%, 5 \%$, and $10 \%$ respectively. 
Table 5

Gender diversity and stock liquidity (Propensity score matching)

\begin{tabular}{|c|c|c|c|c|}
\hline \multirow{3}{*}{ Dependent variables } & \multirow{2}{*}{$\begin{array}{r}\text { First-stage } \\
\text { Model } 1 \\
\text { (t-stats) }\end{array}$} & \multicolumn{3}{|c|}{ Second-stage } \\
\hline & & $\begin{array}{r}\text { Model } 2 \\
\text { (t-stats) }\end{array}$ & $\begin{array}{r}\text { Model } 3 \\
\text { (t-stats) }\end{array}$ & $\begin{array}{r}\text { Model } 4 \\
\text { (t-stats) }\end{array}$ \\
\hline & Womend & ILLIQ & $L R$ & TO \\
\hline Gender diversity vari & & & & \\
\hline Percofwomen & & $\begin{array}{r}-1.00 * * * \\
(-3.05)\end{array}$ & $\begin{array}{r}0.71 * * * \\
(4.22)\end{array}$ & $\begin{array}{r}0.26 * * * \\
(4.01)\end{array}$ \\
\hline Governance related v & & & & \\
\hline INDDirector & $\begin{array}{r}0.88 * * * \\
(4.81)\end{array}$ & $\begin{array}{r}-0.53 * * * \\
(-2.73)\end{array}$ & $\begin{array}{r}0.56 * * * \\
(5.60)\end{array}$ & $\begin{array}{r}0.30 * * * \\
(7.94)\end{array}$ \\
\hline BSize & $\begin{array}{r}2.55 * * * \\
(15.55)\end{array}$ & $\begin{array}{r}0.02 \\
(0.16)\end{array}$ & $\begin{array}{l}0.16^{*} \\
(1.75)\end{array}$ & $\begin{array}{r}-0.03 \\
(-0.86)\end{array}$ \\
\hline BMeeting & $\begin{array}{l}-0.17^{*} \\
(-1.87)\end{array}$ & $\begin{array}{r}-0.33 * * * \\
(-3.45)\end{array}$ & $\begin{array}{r}0.15^{* * *} \\
(3.21)\end{array}$ & $\begin{array}{r}0.11 * * * \\
(5.84)\end{array}$ \\
\hline Firm related variable & & & & \\
\hline FSize & $\begin{array}{r}0.19 * * * \\
(4.25)\end{array}$ & $\begin{array}{r}-1.29 * * * \\
(-28.61)\end{array}$ & $\begin{array}{r}1.07 * * * \\
(46.48)\end{array}$ & $\begin{array}{r}0.15^{* * * *} \\
(17.09)\end{array}$ \\
\hline$L E V$ & $\begin{array}{r}0.21 \\
(1.03)\end{array}$ & $\begin{array}{r}-0.19 \\
(-0.92)\end{array}$ & $\begin{array}{r}0.15 \\
(1.46)\end{array}$ & $\begin{array}{c}0.07^{*} \\
(1.72)\end{array}$ \\
\hline RVol & $\begin{array}{r}-8.24 * * \\
(-2.54)\end{array}$ & $\begin{array}{r}17.14^{* * *} \\
(4.65)\end{array}$ & $\begin{array}{r}6.53^{* * *} \\
(3.62)\end{array}$ & $\begin{array}{r}9.44 * * * \\
(13.73)\end{array}$ \\
\hline ATang & $\begin{array}{r}-0.09 \\
(-0.47)\end{array}$ & $\begin{array}{r}1.03 * * * \\
(5.08)\end{array}$ & $\begin{array}{r}-0.44^{* * *} \\
(-4.27)\end{array}$ & $\begin{array}{r}-0.13^{* * *} \\
(-3.41)\end{array}$ \\
\hline SPrice & $\begin{array}{r}-0.04 \\
(-0.88)\end{array}$ & $\begin{array}{r}0.01 \\
(0.12)\end{array}$ & $\begin{array}{r}-0.72 * * * \\
(-31.49)\end{array}$ & $\begin{array}{l}-0.01 * \\
(-1.76)\end{array}$ \\
\hline FAge & $\begin{array}{r}0.16^{* * *} \\
(3.42)\end{array}$ & $\begin{array}{r}-0.26 * * * \\
(-5.06)\end{array}$ & $\begin{array}{r}0.14^{* * *} \\
(5.38)\end{array}$ & $\begin{array}{r}0.05 * * * \\
(5.50)\end{array}$ \\
\hline GOpp & $\begin{array}{r}-0.06 * * \\
(-2.67)\end{array}$ & $\begin{array}{r}0.06 * * * \\
(2.82)\end{array}$ & $\begin{array}{c}-0.02 * * \\
(-2.00)\end{array}$ & $\begin{array}{r}-0.01 * * \\
(-2.14)\end{array}$ \\
\hline Year fixed effects & Yes & Yes & Yes & Yes \\
\hline Industry fixed effects & Yes & Yes & Yes & Yes \\
\hline Constant & $\begin{array}{r}-9.56 * * * \\
(-10.58)\end{array}$ & $\begin{array}{r}11.05^{* * *} \\
(11.46)\end{array}$ & $\begin{array}{r}-22.18^{* * *} \\
(-44.90)\end{array}$ & $\begin{array}{r}-3.28 * * * \\
(-17.42)\end{array}$ \\
\hline $\mathrm{R}^{2}$ & 0.21 & 0.64 & 0.63 & 0.36 \\
\hline Obs. & 4,608 & 2,502 & 2,502 & 2,502 \\
\hline
\end{tabular}

See Appendix A for variable definitions.

Figures in parenthesis are the t-statistics. Superscripts ***, **, * indicate statistical significance at $1 \%, 5 \%$, and $10 \%$ respectively. 


\section{Table 6}

Regression based on average differenced variables surrounding the gender diversity reforms

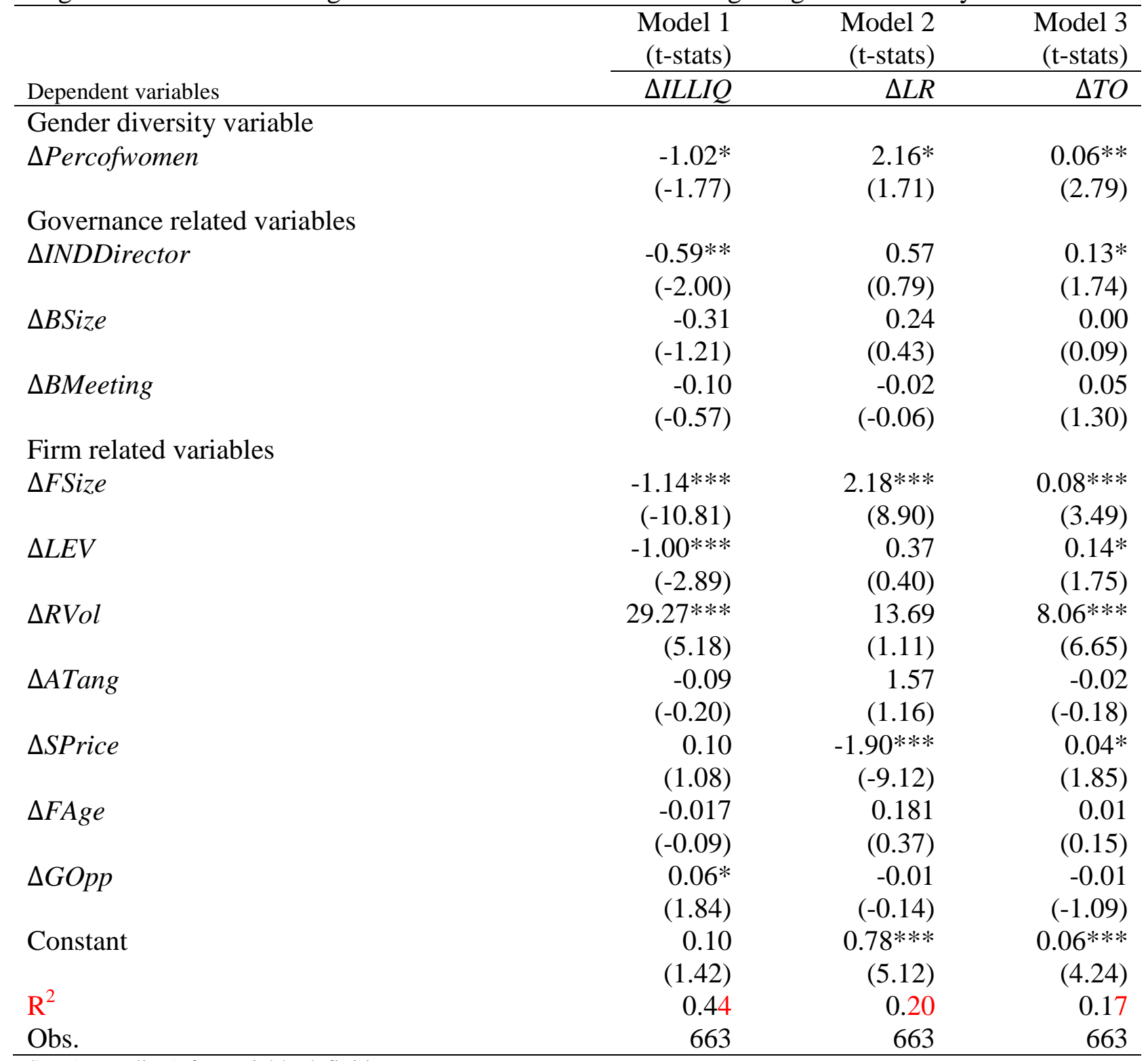

See Appendix A for variable definitions.

Figures in parenthesis are the t-statistics. Superscripts ***, **, * indicate statistical significance at $1 \%, 5 \%$, and $10 \%$ respectively. 
Table 7

Critical mass theory and non-linear relationship

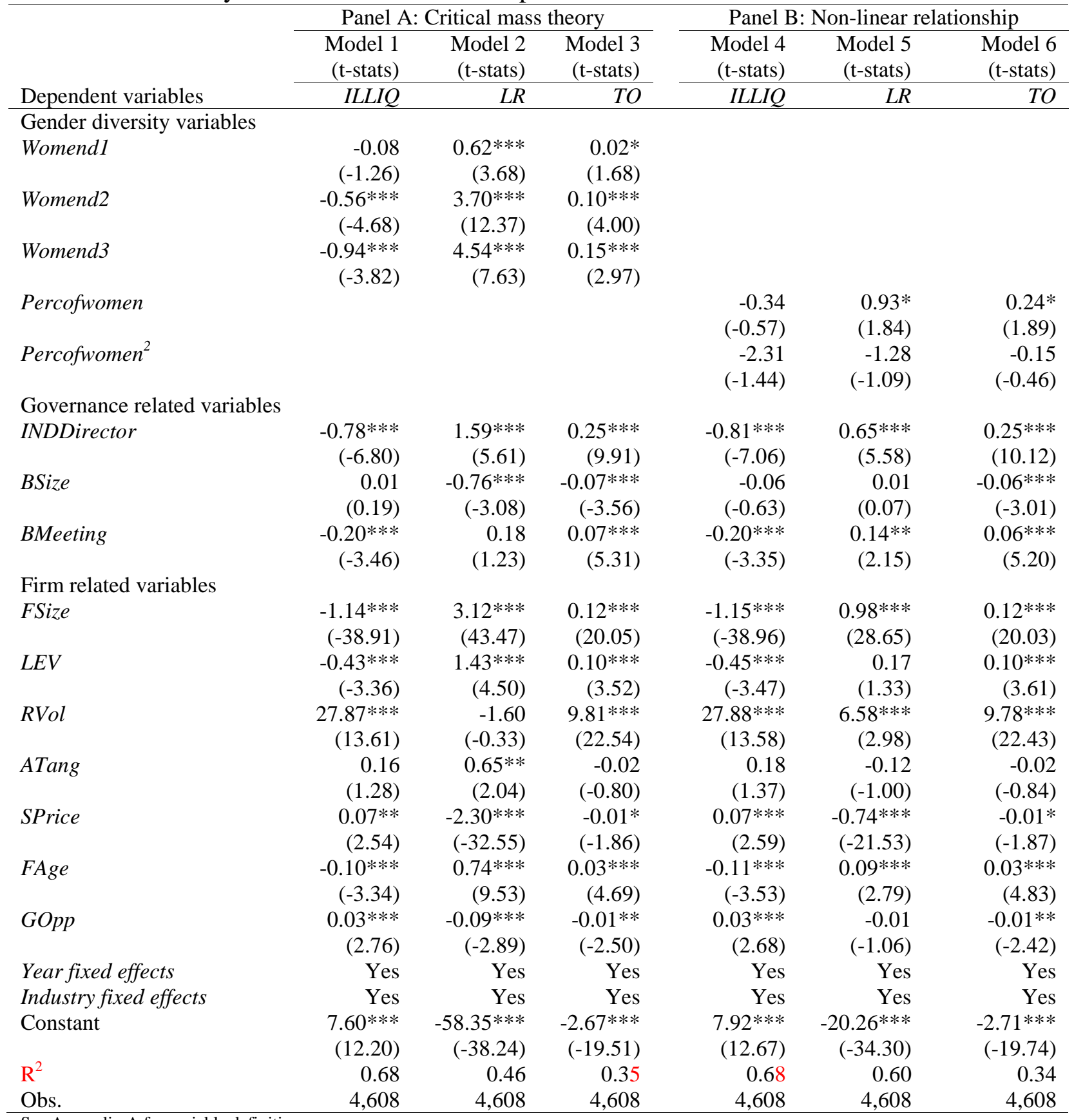

See Appendix A for variable definitions.

Figures in parenthesis are the t-statistics. Superscripts ***, **, * indicate statistical significance at $1 \%, 5 \%$, and $10 \%$ respectively. 
Table 8

Gender diversity, board strength and stock liquidity

\begin{tabular}{|c|c|c|c|c|c|c|c|}
\hline & $\begin{array}{r}\text { Model } 1 \\
\text { (t-stats) }\end{array}$ & $\begin{array}{r}\text { Model } 2 \\
\text { (t-stats) }\end{array}$ & $\begin{array}{r}\text { Model } 3 \\
\text { (t-stats) }\end{array}$ & $\begin{array}{r}\text { Model } 4 \\
\text { (t-stats) }\end{array}$ & $\begin{array}{r}\text { Model } 5 \\
\text { (t-stats) } \\
\end{array}$ & $\begin{array}{r}\text { Model } 6 \\
\text { (t-stats) }\end{array}$ & $\begin{array}{r}\text { Model } 7 \\
\text { (t-stats) }\end{array}$ \\
\hline Dependent variables & BStrength & ILLIQ & $L R$ & TO & ILLIQ & $L R$ & TO \\
\hline \multicolumn{8}{|c|}{ Gender diversity variable } \\
\hline \multirow[t]{2}{*}{ Percofwomen } & $1.14^{* *}$ & & & & $-1.07^{* *}$ & $0.63 * *$ & $0.23 * *$ \\
\hline & $(2.12)$ & & & & $(-2.21)$ & $(2.43)$ & $(2.30)$ \\
\hline \multicolumn{8}{|c|}{ Governance related variables } \\
\hline \multirow[t]{2}{*}{ BStrength } & & $-0.04 * * *$ & $0.03^{* * *}$ & $0.01^{* * *}$ & $-0.04 * * *$ & $0.03^{* * *}$ & $0.01^{* * *}$ \\
\hline & & $(-3.18)$ & (3.52) & $(4.92)$ & $(-3.17)$ & (3.53) & (4.93) \\
\hline \multirow[t]{2}{*}{ BSize } & $3.14^{* * *}$ & 0.03 & -0.05 & $-0.09 * * *$ & 0.08 & -0.08 & $-0.11 * * *$ \\
\hline & $(15.72)$ & $(0.18)$ & $(-0.51)$ & $(-2.80)$ & $(0.52)$ & $(-0.84)$ & $(-3.09)$ \\
\hline \multicolumn{8}{|l|}{ Firm related variables } \\
\hline \multirow[t]{2}{*}{ FSize } & $0.87^{* * *}$ & $-1.17 * * *$ & $1.01^{* * *}$ & $0.14^{* * *}$ & $-1.16^{* * *}$ & $1.00^{* * *}$ & $0.13^{* * *}$ \\
\hline & $(15.30)$ & $(-19.35)$ & $(28.34)$ & $(11.08)$ & $(-19.29)$ & $(28.03)$ & $(11.06)$ \\
\hline \multirow[t]{2}{*}{$L E V$} & $2.83^{* * *}$ & $-0.47 * *$ & 0.19 & $0.11^{* *}$ & $-0.45^{* *}$ & 0.18 & $0.11^{* *}$ \\
\hline & (11.93) & $(-2.25)$ & $(1.41)$ & $(2.29)$ & $(-2.17)$ & (1.34) & $(2.21)$ \\
\hline \multirow[t]{2}{*}{$R V o l$} & -3.14 & $27.95^{* * *}$ & $6.84^{* * *}$ & $9.90^{* * *}$ & $27.71 * * *$ & $7.05^{* * *}$ & $9.97 * * *$ \\
\hline & $(-0.82)$ & $(8.61)$ & (3.13) & (15.09) & $(8.60)$ & $(3.22)$ & $(15.19)$ \\
\hline \multirow[t]{2}{*}{ ATang } & -0.04 & 0.21 & -0.14 & -0.03 & 0.20 & -0.14 & -0.03 \\
\hline & $(-0.17)$ & $(0.83)$ & $(-1.09)$ & $(-0.62)$ & $(0.77)$ & $(-1.05)$ & $(-0.59)$ \\
\hline \multirow[t]{2}{*}{ SPrice } & $0.17^{* * *}$ & 0.08 & $-0.75 * * *$ & -0.01 & 0.08 & $-0.75^{* * *}$ & -0.01 \\
\hline & (2.98) & $(1.54)$ & $(-21.51)$ & $(-1.24)$ & $(1.51)$ & $(-21.43)$ & $(-1.21)$ \\
\hline \multirow[t]{2}{*}{ FAge } & $-0.35 * * *$ & $-0.14^{* *}$ & $0.11^{* * *}$ & $0.04 * * *$ & $-0.13^{* *}$ & $0.11^{* * *}$ & $0.04 * * *$ \\
\hline & $(-5.45)$ & $(-2.52)$ & (3.37) & (3.49) & $(-2.37)$ & (3.26) & (3.37) \\
\hline \multirow[t]{2}{*}{ GOpp } & $-0.30 * * *$ & $0.04 *$ & -0.02 & $-0.01^{*}$ & $0.03 *$ & -0.01 & -0.01 \\
\hline & $(-11.69)$ & (1.90) & $(-1.31)$ & $(-1.74)$ & $(1.78)$ & $(-1.20)$ & $(-1.64)$ \\
\hline Year fixed effects & Yes & Yes & Yes & Yes & Yes & Yes & Yes \\
\hline Industry fixed effects & Yes & Yes & Yes & Yes & Yes & Yes & Yes \\
\hline \multirow[t]{2}{*}{ Constant } & $-11.84 * * *$ & $7.65^{* * *}$ & $-20.22^{* * *}$ & $-2.63^{* * *}$ & $7.42^{* * *}$ & $-20.10^{* * *}$ & $-2.58 * * *$ \\
\hline & $(-6.12)$ & (6.86) & $(-34.16)$ & $(-12.93)$ & $(6.70)$ & $(-33.85)$ & $(-13.00)$ \\
\hline $\mathrm{R}^{2}$ & 0.41 & 0.67 & 0.59 & 0.33 & 0.67 & 0.59 & 0.33 \\
\hline Obs. & 4,608 & 4,608 & 4,608 & 4,608 & 4,608 & 4,608 & 4,608 \\
\hline
\end{tabular}

See Appendix A for variable definitions.

Figures in parenthesis are the t-statistics. Superscripts ***,**, * indicate statistical significance at $1 \%, 5 \%$, and $10 \%$ respectively. 


\section{References}

Abbott, L. J., Parker, S., Presley, T. J., 2012. Female board presence and the likelihood of financial restatement. Accounting Horizons. 26, (4), 607-629.

Adams, R. B., Ferreira, D., 2009. Women in the boardroom and their impact on governance and performance. Journal of financial economics. 94, (2), 291-309.

Adams, R. B., Gray, S., Nowland, J., 2011. Does gender matter in the boardroom? Evidence from the market reaction to mandatory new director announcements. Working Paper. Retrieved from https://papers.ssrn.com/sol3/papers2.cfm?abstract_id=1953152

Ahmed, A., Ng, C., Delaney, D., 2015. Women on corporate boards and the incidence of receiving a 'strike'on the remuneration report. CORPORATE OWNERSHIP \& CONTROL. 12, (4), 261-272.

AICD. 2015. Boards should adopt 30 per cent target for female directors. Retrieved 23rd April 2016, from http:/www.companydirectors.com.au/general/header/media/mediareleases/2015/boards-should-adopt-30-per-cent-target-for-female-directors

Al-Shaer, H., Zaman, M., 2016. Board gender diversity and sustainability reporting quality. Journal of Contemporary Accounting \& Economics. 12, (3), 210-222.

Ali, S., Liu, B., Su, J., 2014. Does corporate governance quality reduce financial distress? New panel evidence from Australia. Paper presented at the 27th Australasian Finance and Banking Conference.

Ali, S., Liu, B., Su, J. J., 2016. What determines stock liquidity in Australia? Applied Economics. 48, (35), 3329-3344.

Amihud, Y., 2002. Illiquidity and stock returns: cross-section and time-series effects. Journal of Financial Markets. 5, (1), 31-56.

Amihud, Y., Mendelson, H., 1986. Asset pricing and the bid-ask spread. Journal of financial Economics. 17, (2), 223-249.

Amihud, Y., Mendelson, H., 2000. The liquidity route to a lower cost of capital. Journal of Applied Corporate Finance. 12, (4), 8-25.

Amihud, Y., Mendelson, H., Lauterbach, B., 1997. Market microstructure and securities values: Evidence from the Tel Aviv Stock Exchange. Journal of financial economics. 45, (3), 365-390.

Arun, T. G., Almahrog, Y. E., Aribi, Z. A., 2015. Female directors and earnings management: Evidence from UK companies. International Review of Financial Analysis. 39, 137-146.

Attig, N., Fong, W.-M., Gadhoum, Y., Lang, L. H., 2006. Effects of large shareholding on information asymmetry and stock liquidity. Journal of Banking \& Finance. 30, (10), 2875-2892.

Bajtelsmit, V. L., Bernasek, A., Jianakoplos, N. A., 1999. Gender differences in defined contribution pension decisions. Financial Services Review. 8, (1), 1-10.

Baltagi, B. H. 2005. Econometric Analysis of Panel Data, John Wiley and Sons, Chichester.

Barber, B. M., Odean, T., 2001. Boys will be boys: Gender, overconfidence, and common stock investment. Quarterly journal of Economics. 116, (1), 261-292.

Bartov, E., Bodnar, G. M., 1996. Alternative accounting methods, information asymmetry and liquidity: Theory and evidence. Accounting Review. 71, (3), 397-418.

Beekes, W., Brown, P., Zhang, Q., 2015. Corporate governance and the informativeness of disclosures in Australia: a re-examination. Accounting \& Finance. 55, (4), 931-963.

Berkman, H., Eleswarapu, V. R., 1998. Short-term traders and liquidity: a test using Bombay Stock Exchange. Journal of financial economics. 47, (3), 339-355. 
Blau, P. M. 1977. Inequality and heterogeneity: A primitive theory of social structure. New York, Free Press.

Bøhren, Ø., Staubo, S., 2014. Does mandatory gender balance work? Changing organizational form to avoid board upheaval. Journal of Corporate Finance. 28, 152-168.

Brennan, M., Huh, S.-W., Subrahmanyam, A., 2013. An analysis of the Amihud illiquidity premium. Review of Asset Pricing Studies. 3, (1), 133-176.

Butler, A. W., Grullon, G., Weston, J. P., 2005. Can managers forecast aggregate market returns? The Journal of Finance. 60, (2), 963-986.

Campbell, K., Mínguez-Vera, A., 2008. Gender diversity in the boardroom and firm financial performance. Journal of business ethics. 83, (3), 435-451.

Carter, D. A., D'Souza, F., Simkins, B. J., Simpson, W. G., 2010. The gender and ethnic diversity of US boards and board committees and firm financial performance. Corporate Governance: An International Review. 18, (5), 396-414.

Carter, D. A., Simkins, B. J., Simpson, W. G., 2003. Corporate governance, board diversity, and firm value. Financial review. 38, (1), 33-53.

Chen, C. J., Jaggi, B., 2001. Association between independent non-executive directors, family control and financial disclosures in Hong Kong. Journal of Accounting and Public Policy. 19, (4), 285-310.

Chordia, T., Roll, R., Subrahmanyam, A., 2001. Market liquidity and trading activity. The Journal of Finance. 56, (2), 501-530.

Chordia, T., Roll, R., Subrahmanyam, A., 2008. Liquidity and market efficiency. Journal of financial economics. 87, (2), 249-268.

Chung, K. H., Elder, J., Kim, J.-C., 2010. Corporate Governance and Liquidity. Journal of Financial and Quantitative Analysis. 45, (2), 265-291.

Cohen, J. R., Pant, L. W., Sharp, D. J., 1998. The effect of gender and academic discipline diversity on the ethical evaluations, ethical intentions and ethical orientation of potential public accounting recruits. Accounting Horizons. 12, (3), 250.

Datar, V. T., Naik, N. Y., Radcliffe, R., 1998. Liquidity and stock returns: An alternative test. Journal of Financial Markets. 1, (2), 203-219.

Davidson, R., Goodwin-Stewart, J., Kent, P., 2005. Internal governance structures and earnings management. Accounting \& Finance. 45, (2), 241-267.

Deloitte. 2015. Women in the boardroom

A global perspective. Retrieved 23rd April 2016, from https://www2.deloitte.com/content/dam/Deloitte/global/Documents/Risk/gx-ccg-womenin-the-boardroom-a-global-perspective4.pdf

Diamond, D. W., Verrecchia, R. E., 1991. Disclosure, liquidity, and the cost of capital. The Journal of Finance. 46, (4), 1325-1359.

Dowling, M., Aribi, Z. A., 2013. Female directors and UK company acquisitiveness. International Review of Financial Analysis. 29, 79-86.

Erhardt, N. L., Werbel, J. D., Shrader, C. B., 2003. Board of director diversity and firm financial performance. Corporate Governance: An International Review. 11, (2), 102-111.

Fama, E. F., Jensen, M. C., 1983. Separation of ownership and control. The Journal of Law \& Economics. 26, (2), 301-325.

Fang, V. W., Noe, T. H., Tice, S., 2009. Stock market liquidity and firm value. Journal of financial economics. 94, (1), 150-169. 
Farber, D. B., 2005. Restoring trust after fraud: Does corporate governance matter? The Accounting Review. 80, (2), 539-561.

Farrell, K. A., Hersch, P. L., 2005. Additions to corporate boards: the effect of gender. Journal of Corporate Finance. 11, (1), 85-106.

Foo, Y.-B., Zain, M. M., 2010. Board independence, board diligence and liquidity in Malaysia: A research note. Journal of Contemporary Accounting \& Economics. 6, (2), 92-100.

Gjerde, T., Mahenthiran, S., Cademartori, D., 2013. Effect of ownership, governance, and transparency on liquidity-Chilean evidence. Journal of Contemporary Accounting \& Economics. 9, (2), 183-202.

Goyenko, R. Y., Holden, C. W., Trzcinka, C. A., 2009. Do liquidity measures measure liquidity? Journal of financial economics. 92, (2), 153-181.

Gul, F. A., Srinidhi, B., Ng, A. C., 2011. Does board gender diversity improve the informativeness of stock prices? Journal of Accounting and Economics. 51, (3), 314-338.

Gul, F. A., Srinidhi, B., Tsui, J. S., 2008. Board diversity and the demand for higher audit effort. Working Paper. Retrieved from http://ssrn.com/paper=1359450

Handa, P., Schwartz, R. A., 1996. Limit order trading. The Journal of Finance. 51, (5), 18351861.

Harrison, D. A., Klein, K. J., 2007. What's the difference? Diversity constructs as separation, variety, or disparity in organizations. Academy of management review. 32, (4), 11991228.

Hasbrouck, J., 2009. Trading costs and returns for US equities: Estimating effective costs from daily data. The Journal of Finance. 64, (3), 1445-1477.

Hillman, A. J., Shropshire, C., Cannella, A. A., 2007. Organizational predictors of women on corporate boards. Academy of Management Journal. 50, (4), 941-952.

Ho, T., Stoll, H. R., 1981. Optimal dealer pricing under transactions and return uncertainty. Journal of financial economics. 9, (1), 47-73.

Jensen, M. C., 1993. The modern industrial revolution, exit, and the failure of internal control systems. The journal of finance. 48, (3), 831-880.

Jensen, M. C., Meckling, W. H., 1976. Theory of the firm: Managerial behavior, agency costs and ownership structure. Journal of financial economics. 3, (4), 305-360.

Jiang, C. X., Kim, J. C., Kuvvet, E., 2014. Market Liquidity and Ambiguity: The Certification Role of Corporate Governance. Financial review. 49, (4), 643-668.

Jiraporn, P., Chatjuthamard, P., Tong, S., Kim, Y. S., 2015. Does corporate governance influence corporate risk-taking? Evidence from the Institutional Shareholders Services (ISS). Finance Research Letters. 13, 105-112.

Joecks, J., Pull, K., Vetter, K., 2013. Gender diversity in the boardroom and firm performance: What exactly constitutes a “critical mass?”. Journal of business ethics. 118, (1), 61-72.

Jurkus, A. F., Park, J. C., Woodard, L. S., 2011. Women in top management and agency costs. Journal of Business Research. 64, (2), 180-186.

Kanagaretnam, K., Lobo, G. J., Whalen, D. J., 2007. Does good corporate governance reduce information asymmetry around quarterly earnings announcements? Journal of Accounting and Public Policy. 26, (4), 497-522.

Karamanou, I., Vafeas, N., 2005. The association between corporate boards, audit committees, and management earnings forecasts: An empirical analysis. Journal of accounting research. 43, (3), 453-486. 
Karolyi, G. A., Lee, K.-H., Van Dijk, M. A., 2012. Understanding commonality in liquidity around the world. Journal of financial economics. 105, (1), 82-112.

Kramer, V. W., Konrad, A. M., Erkut, S., Hooper, M. J. 2006. Critical mass on corporate boards: Why three or more women enhance governance, Wellesley Centers for Women Boston.

Kristie, J., 2011. The power of three. Dir. Boards. 35, (5), 22-32.

Lee, L.-E., Marshall, R., Rallis, D., Moscardi, M., 2015. Global trends in gender diversity on corporate boards. MSCI. Retrieved from https://www.msci.com/documents/10199/04b6f646-d638-4878-9c61-4eb91748a82b

Lei, Q., Lin, B., Wei, M., 2013. Types of agency cost, corporate governance and liquidity. Journal of Accounting and Public Policy. 32, (3), 147-172.

Lennox, C., Lisowsky, P., Pittman, J., 2013. Tax aggressiveness and accounting fraud. Journal of accounting research. 51, (4), 739-778.

Lesmond, D. A., 2005. Liquidity of emerging markets. Journal of financial economics. 77, (2), 411-452.

Levine, R., Zervos, S., 1996. Stock market development and long-run growth. The World Bank Economic Review. 10, (2), 323-339.

Liu, Y., Wei, Z., Xie, F., 2014. Do women directors improve firm performance in China? Journal of Corporate Finance. 28, 169-184.

Loukil, N., Raissa, Y. W.-k., Yousfi, O., 2015. Gender Diversity on Board and Stock Market Liquidity: Empirical Evidence from the French Market. Working Paper. Retrieved from https://papers.ssrn.com/sol3/papers2.cfm?abstract_id=2624013

Matolcsy, Z., Tyler, J., Wells, P., 2012. Is continuous disclosure associated with board independence? Australian Journal of Management. 37, (1), 99-124.

Milliken, F. J., Martins, L. L., 1996. Searching for common threads: Understanding the multiple effects of diversity in organizational groups. Academy of management review. 21, (2), 402-433.

Nakano, M., Nguyen, P., 2012. Board size and corporate risk taking: Further evidence from Japan. Corporate Governance: An International Review. 20, (4), 369-387.

Nielsen, S., Huse, M., 2010. The contribution of women on boards of directors: Going beyond the surface. Corporate Governance: An International Review. 18, (2), 136-148.

Noe, C. F., 1999. Voluntary disclosures and insider transactions. Journal of Accounting and Economics. 27, (3), 305-326.

Pathan, S., 2009. Strong boards, ceo power and bank risk-taking. Journal of Banking \& Finance. 33, (7), 1340-1350.

Peng, M. W., 2004. Outside directors and firm performance during institutional transitions. Strategic Management Journal. 25, (5), 453-471.

Petersen, M. A., 2009. Estimating standard errors in finance panel data sets: Comparing approaches. Review of financial studies. 22, (1), 435-480.

Prommin, P., Jumreornvong, S., Jiraporn, P., 2014. The effect of corporate governance on stock liquidity: The case of Thailand. International Review of Economics \& Finance. 32, 132142.

Rutherford, M. A., Buchholtz, A. K., 2007. Investigating the relationship between board characteristics and board information. Corporate Governance: An International Review. 15, (4), 576-584. 
Srinidhi, B., Gul, F. A., Tsui, J., 2011. Female Directors and Earnings Quality. Contemporary Accounting Research. 28, (5), 1610-1644.

Strydom, M., Yong, H. H. A., Rankin, M., 2016. A few good (wo) men? Gender diversity on Australian boards. Australian Journal of Management. Forthcoming.

Titus, M. A., 2007. Detecting selection bias, using propensity score matching, and estimating treatment effects: An application to the private returns to a master's degree. Research in Higher Education. 48, (4), 487-521.

Trinidad, C., Normore, A. H., 2005. Leadership and gender: a dangerous liaison? Leadership \& Organization Development Journal. 26, (7), 574-590.

Upadhyay, A., Zeng, H., 2014. Gender and ethnic diversity on boards and corporate information environment. Journal of Business Research. 67, (11), 2456-2463.

Vafeas, N., 1999. Board meeting frequency and firm performance. Journal of financial economics. 53, (1), 113-142.

Wang, Y., Clift, B., 2009. Is there a "business case" for board diversity? Pacific Accounting Review. 21, (2), 88-103.

Wintoki, M. B., Linck, J. S., Netter, J. M., 2012. Endogeneity and the dynamics of internal corporate governance. Journal of financial economics. 105, (3), 581-606.

Wooldridge, J. M. 2002. Econometric analysis of cross section and panel data, MIT press, Cambridge, Massachusetts, London. 


\section{Appendix A}

Variable definitions and/or measurements

\begin{tabular}{|c|c|}
\hline Variable name & Measure \\
\hline \multicolumn{2}{|c|}{ Panel A:Stock liquidity measures } \\
\hline $\begin{array}{l}\text { Amihud illiquidity estimate } \\
\text { (ILLIQ) }\end{array}$ & $\begin{array}{l}\text { Natural logarithm of the daily ratio of absolute stock return to trading volume } \\
\text { in Australian dollars averaged over a number of trading days in the financial } \\
\text { year }\end{array}$ \\
\hline Liquidity ratio $(L R)$ & $\begin{array}{l}\text { Sum of daily trading volume to the sum of absolute stock return in a financial } \\
\text { year }\end{array}$ \\
\hline Stock turnover $(T O)$ & $\begin{array}{l}\text { Sum of daily shares traded to the number of shares outstanding in the financial } \\
\text { year }\end{array}$ \\
\hline Number of trades (Trade) & Average of number of transactions during the financial year \\
\hline Number of levels (Level) & Average of number of levels during the financial year \\
\hline Trading volume (Volume) & Total number of shares traded during the financial year \\
\hline \multicolumn{2}{|l|}{ Panel B: Gender diversity variables } \\
\hline $\begin{array}{l}\text { Women to board ratio } \\
\text { (Percofwomen) }\end{array}$ & $\begin{array}{l}\text { The number of women directors on boards expressed as a percentage of total } \\
\text { board size. }\end{array}$ \\
\hline $\begin{array}{l}\text { Women to men ratio } \\
\text { (Percwomen2men) }\end{array}$ & $\begin{array}{l}\text { The number of women directors on boards expressed as a percentage of men } \\
\text { directors. }\end{array}$ \\
\hline $\begin{array}{l}\text { Women dichotomous variable } \\
\text { (Womend) }\end{array}$ & $\begin{array}{l}\text { A dichotomous variable equal to ' } 1 \text { ' if firm has at least one woman director on } \\
\text { the board and ' } 0 \text { ' otherwise. }\end{array}$ \\
\hline Heterogeneous board (Blau) & See equation 4 for measurement of Blau index. \\
\hline 1 (Womend1) & $\begin{array}{l}\text { A dummy variable equal to ' } 1 \text { ' if firm has one woman director on the board } \\
\text { and ' } 0 \text { ' otherwise. }\end{array}$ \\
\hline Women dummy 2 (Womend2) & $\begin{array}{l}\text { A dummy variable equal to ' } 1 \text { ' if firm has two women directors on the board } \\
\text { and ' } 0 \text { ' otherwise. }\end{array}$ \\
\hline Women dummy 3 (Womend3) & $\begin{array}{l}\text { A dummy variable equal to ' } 1 \text { ' if firm has three or more women directors on } \\
\text { the board and ' } 0 \text { ' otherwise. }\end{array}$ \\
\hline Gender reform (GReform) & $\begin{array}{l}\text { A dummy variable equal to ' } 1 \text { ' for the years from } 2011 \text { to } 2013 \text { and '0' } \\
\text { otherwise. }\end{array}$ \\
\hline Fitted_P & Predicted percentage of women on boards from the first stage of 2SLS. \\
\hline Percofwomen $^{2}$ & Square term of percentage of women on boards \\
\hline \multicolumn{2}{|c|}{ Panel C: Governance related variables } \\
\hline $\begin{array}{l}\text { Independent directors ratio } \\
\text { (INDDirector) }\end{array}$ & $\begin{array}{l}\text { Number of independent directors on the board expressed as a percentage of } \\
\text { total board size. }\end{array}$ \\
\hline Board siz & Natural logarithm of the number of directors on the board. \\
\hline Bo & Natural logarithm of the number of board meetings held in a financial year. \\
\hline Board strength (BStrength) & $\begin{array}{l}\text { Self-constructed board strength index based on } 17 \text { provisions related to } \\
\text { independence of board and its sub-committees (Appendix B). }\end{array}$ \\
\hline \multicolumn{2}{|l|}{$\underline{\text { Panel D: Firm related variables }}$} \\
\hline Firm size (FSize) & $\begin{array}{l}\text { Natural logarithm of the number of outstanding shares multiplied with market } \\
\text { price per share }\end{array}$ \\
\hline Lever & Total liabilities divided by total assets \\
\hline Return volatility $(R V o l)$ & Standard deviation of daily stock returns in a financial year. \\
\hline ibility (ATang) & Net property, plant and equipment to total assets \\
\hline ice (SPrice) & Natural logarithm of stock price \\
\hline Firm age (FAge) & $\begin{array}{l}\text { Natural logarithm of number of years firm has been listed on the ASX at the } \\
\text { end of its financial year }\end{array}$ \\
\hline sOpp) & Market value divided by book value of equity \\
\hline Year fixed effect (Year) & $\begin{array}{l}\text { Six separate dummy variables which equal either ' } 1 \text { ' or ' } 0 \text { ' for each year from } \\
2008 \text { to } 2013 \text {, with } 2008 \text { being the excluded year. }\end{array}$ \\
\hline Industry fixed effect (Industry) & $\begin{array}{l}\text { Nine separate dummy variables which equal either ' } 1 \text { ' or ' } 0 \text { ' for each industry } \\
\text { (based on GICS). }\end{array}$ \\
\hline
\end{tabular}




\section{Appendix B}

Provisions of board strength index

Provisions

Yes

No

Board of Directors

A board with the majority of independent directors

An independent chairperson; and

10

Met at least six times annually

$\begin{array}{ll}1 & 0 \\ 1 & 0\end{array}$

Audit Committee

Existence of audit committee

With all the members, including the chair, independent;

With a chair, who is not also the chair of the main board;

With at least three members;

That does not comprise the full board; and

0

That meets at least four times annually.

\begin{tabular}{ll}
1 & 0 \\
1 & 0 \\
1 & 0 \\
1 & 0 \\
1 & 0 \\
1 & 0 \\
\hline
\end{tabular}

Remuneration Committee

Existence of remuneration committee

With all the members, including the chair, independent;

With at least three members; and

That does not comprise the full board.

\begin{tabular}{ll}
1 & 0 \\
1 & 0 \\
1 & 0 \\
1 & 0 \\
\hline
\end{tabular}

Nomination Committee

Existence of nomination committee

With all the members, including the chair, independent;

With at least three members; and

That does not comprise the full board

Total

\begin{tabular}{cc}
1 & 0 \\
1 & 0 \\
1 & 0 \\
1 & 0 \\
\hline 17 & 0 \\
\hline
\end{tabular}

